\title{
Ulusal Pazarlama Yazınında Yer Alan Nitel Makalelerin İncelenmesi (Review of the Qualitative Articles Published in National Marketing Literature)
}

\section{Muhammet Ali TILTAY iD a Ayhan AKPINAR iD b}

a Eskişehir Osmangazi Üniversitesi, İktisadi ve İdari Bilimler Fakültesi, Eskişehir, Türkiye. matitlay@ogu.edu.tr b KTO Karatay Üniversitesi, İktisadi ve İdari Bilimler Fakültesi, Konya, Türkiye. ayhan.akpinar@karatay.edu.tr,

\begin{tabular}{|c|c|}
\hline MAKALE BİLGİSİ & ÖZET \\
\hline \multirow{5}{*}{$\begin{array}{l}\text { Anahtar Kelimeler: } \\
\text { Pazarlama } \\
\text { Nitel Araştırma } \\
\text { Geçerlik } \\
\text { Güvenirlik }\end{array}$} & Amaç - Bu araştırmanın amacı, ulusal yazında yer alan, pazarlama disiplini içerisinde yayınlanmış \\
\hline & $\begin{array}{l}\text { nitel çalışmaların incelenmesidir. İkincil olarak nitel araştırmalarda karşılaşılabilecek sorunlar ile } \\
\text { cözümleri irdelenecek ve bu amac doŏrultusunda secilen makalelerden vararlanılacaktır. }\end{array}$ \\
\hline & \\
\hline & Yöntem - Bu kapsamda yalnızca pazarlama odaklı yayınlar yapan beş adet dergi belirlenmiş \\
\hline & $\begin{array}{l}\text { (PPAD, PATU, TTAD, GIPAD ve SOMI) ve burada yer alan nitel çalışmalar, temaları, desenleri, } \\
\text { analiz teknikleri, veri toplama yöntemleri, güvenirliği ve geçerliği gibi başlıklar çerçevesinde ele }\end{array}$ \\
\hline Gönderilme Tarihi 3 Şubat 2021 & alınarak içerik analizine tabi tutulmuştur. \\
\hline $\begin{array}{l}\text { Revizyon Tarihi } 20 \text { Mart } 2021 \\
\text { Kabul Tarihi } 26 \text { Mart } 2021\end{array}$ & $\begin{array}{l}\text { Bulgular - İncelenen } 33 \text { makalede araştı̈macıların büyük bir bölümünün herhangi bir tasarımla } \\
\text { metodolojilerini şekillendirmedikleri görlmektedir. Seçilen tasarımlar içerisinde büyük oranda } \\
\text { vaka analizi ve fenomenoloji kullanılmıştır. Araştırmacıların büyük bir bölümü içerik analizi } \\
\text { yönteminden yararlanmışlardır. Veri toplama yöntemlerinden en çok kullanılan ise görüşmelerdir. }\end{array}$ \\
\hline \multirow[t]{2}{*}{$\begin{array}{l}\text { Makale Kategorisi: } \\
\text { Araştırma Makalesi }\end{array}$} & $\begin{array}{l}\text { Araştırmacılar geçerlik ve güvenirliği arttırmak adına, çeşitlilik, paranteze alma, akran denetimi, } \\
\text { amaçlı örneklem gibi farklı tekniklerden yararlanmışlardır. }\end{array}$ \\
\hline & $\begin{array}{l}\text { Tartışma - Genel anlamda araştırmacıların geçerlik ve güvenirliği arttırmak için daha fazla } \\
\text { teknikten yararlanmaları, kullandıkları tasarım, yöntem, stratejilerle ilgili daha şeffaf ve açılayıcı } \\
\text { olmaları ve örneklem büyüklüğü ve zenginliği konularına daha fazla dikkat etmeleri } \\
\text { beklenmektedir. }\end{array}$ \\
\hline
\end{tabular}

\section{ARTICLE INFO}

\section{Keywords:}

Marketing

Qualitative Research

Validity

Reliability

Received 3 February 2021

Revised 20 March 2021

Accepted 26 March 2021

Article Classification:

Research Article

\section{ABSTRACT}

Purpose - The aim of this study is to examine qualitative studies published in the literature within the marketing discipline. Secondly, the problems that may be encountered in qualitative research and their solutions will be examined and articles selected for this purpose will be used.

Design/methodology/approach - In this context, five journals that only publish marketing-oriented publications (PPAD, PATU, TTAD, GIPAD and SOMI) were determined and the qualitative studies included here were handled within the framework of topics such as themes, designs, analysis techniques, data collection methods, reliability and validity was subjected to content analysis.

Results - In the 33 articles examined, it is seen that most of the researchers did not shape their methodologies with any design. Case analysis and phenomenology were used to a large extent among the selected designs. Most of the researchers have conducted the content analysis method. The most used data collection method is interviews. Researchers have used different techniques such as triangulation, bracketing, peer review, purposive sampling in order to increase validity and reliability.

Discussion - In general, researchers are expected to use more techniques to increase validity and reliability, to be more transparent and descriptive about the design, method, and strategies they use, and to pay more attention to sample size and richness. 


\section{Gíríş}

Pazarlamanın bilimsel statüsü ile ilgili tartışmalar, akademik olarak ortaya çıktığı 20.yy'ın ortalarından itibaren süregelmektedir (Alderson ve Cox, 1948; Hunt, 1976). Pazarlamanın uygulama tarafına odaklanarak onu sanat olarak tanımlayanlar, akademik yönünü öne çıararak disiplin olarak tanımlayanlar ve kendi kavramları, teorileri, ilke ve yasalarının olduğunu vurgulayarak bilim olarak tanımlayanlar bulunmaktadır (Baker, 1995). Pazarlama içerisinde bu tartışmalar yapılırken, diğer taraftan bilimin ne olduğu ile ilgili birtakım genel kabuller de benzer dönemlerde sorgulanmaya başlanmıştır (Kuhn ve Hawkins, 1963). Bilim felsefesinde hâkim anlayış olan pozitivist paradigmanın yeri sarsılmaya başlamış ve etkileri başta iktisat, psikoloji ve sosyoloji olmak üzere kendisini sosyal bilim olarak tanımlayan tüm disiplinlere yansımıştır. Tarihsel olarak bakıldığında pazarlama disiplininin, teorik anlamda ilk kez iktisadın bir alt dalı olarak tartışıldığı bilinmektedir (Dixon, 1981). Pazarlamanın akademik açıdan ilk yılları incelendiğinde; Alman tarihselci ekonomi ekolünün felsefi perspektifinin etkisinde kaldığı ve paradigmasının ABD'de pozitivist geleneğin ağır bastığı Harvard ve Wisconsin Üniversiteleri tarafından şekillendirildiğini görmek mümkündür (Jones ve Monieson, 1990). Hem iktisat disiplinin etkileri (Erdoğan ve Doğan, 2012) hem de geliştiği okullar dolayısıyla pozitivist paradigmanın pazarlama alanındaki hakimiyeti, özellikle 1980'li yıllara dek sürmüştür (Hanson ve Grimmer, 2007). Daha sonra ise çeşitli paneller, önde gelen dergilerin özel sayıları ve kongreler vasıtasıyla pazarlama araştırmalarında kullanılan metodolojiler irdelenmeye başlanmıştır (Hunt, 2014). Yine aynı yıllar, başlıca pazarlama dergilerinde nitel çalışmaların ağılıklarının arttığı ve bu tür çalışmaların yoğun olarak yayınlandığı yeni dergilerin de ortaya çıktı̆̆ bir dönemdir (Ger, 2009). Tüm bu gelişmelere rağmen nicel çalışmaların baskınlığını çok da kaybetmediği görülmektedir. 1993-2002 yılları arasında pazarlamanın başat üç dergisinde yayınlanan her üç ampirik makaleden ikisinin nicel yöntemlerle yazıldığı belirtilmelidir (Hanson ve Grimmer, 2007). Pazarlamada tek bir baskın paradigma olmadığı ifade edilse de (Hunt, 1994) nicel metotların ve pozitivist bakış açısının ağırlığı yadsınamamaktadır (Gummesson, 2005). Yalnızca pazarlamada değil; iktisat ve psikoloji gibi bazı sosyal bilimlerde de yapılan bibliyometrik taramalar incelendiğinde halen pozitivist gelenek ve nicel yöntem eğiliminin sürdüğü anlaşılmaktadır (Kidd, 2002; Starr, 2014). Bu durumun sosyal bilimlerde pozitivist yaklaşımların bilim yapma yolu olarak görülmesi ve bilimsel statü kazanmak için doğa bilimlerinin yöntemlerini kullanmanın bir zorunluluk olduğu nosyonundan kaynaklandığı düşünülmektedir (Yıldırım, 2002). Türkiye'deki pazarlama yazınına bakıldığında ise nitel araştırma yöntemlerine ilginin az olduğu ve hatta geciktiği belirtilmektedir (Dedeoğlu, 2002). Bu durum başka çalışmaların bulgularıyla da desteklenmektedir. Örneğin, Arı vd. (2009) pazarlama ve yönetim alanında 19902005 yılları arasında yazılmış olan yüksek lisans tezlerini bibliyometrik olarak incelediklerinde, 140 araştırmadan yalnızca 22'sinin nitel yöntem kullandığını tespit etmişlerdir. Bir diğer çalışmada ise Bakır (2014), 1994-2012 arasında pazarlama alanında yapılan doktora tezlerini değerlendirmiş ve yalnızca \%15'inin nitel yöntemlerden yararlandığı sonucuna ulaşmıştır. Buna karşın makalelerle ilgili yapılan bir çalışmada herhangi bir yöntemin baskın gelmediği görülmüştür. 2004-2016 yılları arasında, ULAKBİM veri tabanına kayıtlı dergilerden, pazarlama konulu 308 ampirik makaleyi inceleyen Çatı ve Öcel (2018), 158 makalede nicel ve 150 makalede nitel yöntem kullanıldığı sonucuna ulaşmışlardır. Sayılar metodolojik olarak neredeyse eşit gözükse de makalelerin nitelikleriyle ilgili bir bilgiye rastlanılmamaktadır. Bu çalışmada, Türkiye'de pazarlama odaklı makaleler yayınlayan beş dergide (PPAD, PATU, TTAD, GIPAD ve SOMI) yer alan nitel çalışmalar incelenerek literatür taraması gerçekleştirilecektir. Araştırmalar; temaları, desenleri, analiz teknikleri, veri toplama yöntemleri, güvenirliği ve geçerliği gibi başlıklar çerçevesinde ele alınarak Türkiye' de pazarlama alanında nitel çalışmaların kapsamı değerlendirilmeye çalışılacaktır. Bununla birlikte, nitel araştırmacıların genel anlamda karşılaştıkları sorunlar ele alınarak, seçilen makaleler üzerinden çözümleri irdelenecektir. Böylece hem pazarlama literatüründe yer alan nitel çalışmaların kapsamı görülecek hem de gelecekte nitel araştırma yapmayı düşünen pazarlama akademisyenlerine ve lisansüstü araştırmacılara veri toplama ve veri analizi süreçlerini nasıl titizlikle yaparak bu sorunların üstesinden gelebilecekleri gösterilmeye çalışılacaktır.

Pazarlamada felsefi olarak yapılan tartışmaların, krizlerin ve teori geliştirmede yaşanan tıkanmaların diğer sosyal bilim dallarında yaşanan hadiselerden çok da farklı olmadığı ortadadır (Hunt, 2014). Kuhn, Popper, Wittgenstein, Lakatos, Althusser ve Feyerabend gibi pek çok yazarın yaptıkları farklı çalışmalar neticesinde, 1960'lardan itibaren pozitivizmin bilim felsefesindeki hegemonyası tartışılmaya başlanmıştır (Demir, 2019). Pozitivist anlayışın ortaya koyduğu tek ve nesnel gerçeklik fikrine şüpheyle yaklaşılmaya başlanılan bu dönemde; bunun yerine gerçekliğin sosyal olarak yapılandığı, çoklu gerçeklerin bir arada olduğu 


\section{A. Tiltay - A. Akpinar 13/1 (2021) 994-1015}

yorumsamacı perspektif öne çıkmıştır (Schwandt, 1994). Yorumsamacı yaklaşımda pozitivizmin aksine epistemolojik anlamda açıklamadan çok anlama üzerinde durulmaktadır. Tüketici davranışı çalışmaları, sadece nicel olarak incelendiğinde, bir takım açıklamalardan öteye gidilemediği düşünüldüğünde (Dedeoğlu, 2002, 2004); bu yaklaşımın pazarlama disiplinine olan etkilerinin çok çabuk gerçekleşmesi sürpriz olmamıştır. $\mathrm{Bu}$ gelişmelerin pazarlama alanına yansıması öncelikle; baskın paradigma olan ve pozitivist temellere dayanan Pazarlama Karmasının (4P) tartışılmaya başlanması ve itibarını kaybetmesiyle sonuçlanmıştır (Erdoğan, 2018). Bu paradigma değişimine paralel olarak yine pek çok pazarlama araştırmacısı kullanılan metodolojileri de sorgulamaya ve tartışmaya başlamıştır. Zira nicel araştırmalarda elde edilen veriler sayısal olarak genellemeye çalışılmakta, sayısal hale getirilen bu değişkenler arasında bir takım neden-sonuç ilişkilerinin incelenmesi araştırmaların asıl amacını oluşturmaktadır. Bu bağlamda, tüketicileri anlamada istatistiksel verilere dayanan nicel araştırmaların daha yüzeysel kaldığı, nitel araştırmaların daha derinlikli bilgi ürettiği savunulmaktadır (Ger, 2009). Diğer taraftan tüketicilerin söylemleri ile uygulamaları arasında çoğu zaman farklılıklar olması ve bunların ortaya çıkartılmasında nitel yöntemlerin kullanılması adeta bir zorunluluk olarak görülmektedir (Dedeoğlu, 2002). Gummesson (2005), nicel paradigmada yer almanın pazarlamanın bilimsel statüsüne katkıda bulunduğunu; ancak bunun yeterli olmadığını ifade etmektedir. Benzer şekilde pek çok yazar, nitel tekniklerin ve stratejilerin pazarlama alanında kullanımının artmasına/yaygınlaşmasına ihtiyaç duyulduğu konusunda hemfikirlerdir. Ancak ana akım pozitivist paradigmanın terk edilerek yorumsamacı veya bilimsel realizm gibi yaklaşımlardan hangisinin benimsenmesi gerektiği konusunda literatürde bir uzlaşı olmaması doğal karşılanmalıdır (Anderson, 1986; Carson ve Coviello, 1996; Healy ve Perry, 2000; Holbrook ve O'Shaughnessy, 1988; Hunt, 1994; Peter ve Olson, 1983). Genellikle çoğu araştırmacının farkında olarak veya olmayarak bilimsel realizm tarafından yönlendirildiğini ifade eden Hunt (1990), pazarlamada yaşanan her türlü krizde ilk suçlunun pozitivizm (mantıksal pozitivizm ya da mantıksal ampirizm olarak adlandırıldığ şekliyle) olarak gösterilmesini de kolaya kaçma olarak tanımlamaktadır. Epistemolojik, ontolojik veya metodolojik olarak, farklı bilim çevrelerinin dünyaya farklı pencerelerden bakıyor olmaları oldukça normaldir. Tüm pazarlama çalışmalarının belirli bir felsefi temeli bulunmaktadır ve pazarlama araştırmacıları arasında her zaman farklılıklar olacağı muhakkaktır. Bu nedenle de bu felsefi tartışmalar hiçbir zaman bitmeyecektir. Bu tartışmaların sağlıklı bir şekilde yapılabilmesi için, tarihsel açıdan bilgilenmiş şekilde yapılması önem arz etmektedir (Hunt, 2014). Bilimsel çalışmaları farklı yollarla yapmak mümkündür; ancak önemli olan, hangi yöntem kullanılırsa kullanılsın; bunu özenle yapmanın ve sağlam bir şekilde gerçekleştirmenin asıl gaye olmasıdır (Ger, 2009). Yukarıdaki tartışmalardan hareketle pazarlamanın teorik anlamda dışarıya oldukça açık bir disiplin olmasının yanı sıra metodolojik ve paradigmatik açılardan da çok sesli olduğu sonucu çıkartılabilmektedir. Araştırmanın metodolojisine ve ardından bulgularına geçmeden önce, bu araştırmanın asıl konusu olan nitel çalışmaların sağlamlığı ve niteliği ile ilgili hususlara kısaca değinilecektir.

Nitel çalışmaların nitelik sorunu, nitel araştırmaların değeri, güvenirlik ve geçerlik sorunlarının nasıl geliştirilebileceği gibi hususlar bilim camiasında halen sıklıkla tartışılmaktadır. Örneğin, geçerlik ve güvenirlik konuları nicel araştırmacılar açısından oldukça oturmuş kavramlardır. Nicel yöntemler uygulanırken, belli bir takım ön kabuller ve uzlaşıların olduğunu görmek mümkündür. Buna karşın bu kavramların nitel çalışmalarda oldukça farklı biçimlerde, dağınık ve hatta gelişigüzel kullanıldığını söylemek yanlış olmayacaktır (Lecompte ve Goetz, 1982). En başta geçerlik ve güvenirlik olmak üzere, nitel araştırmaya getirilen eleştirilerden başlıcaları; nesnellik problemi ve genelleme yapılamamasıdır (Mays ve Pope, 1995). Nitel araştırmaların nicel araştırmalardan epistemolojik ve ontolojik varsayımlar açısından oldukça farklılaşması nedeniyle aynı nitelik ölçütlerinin nitel araştırmalar için geçerli olamayacağı düşüncesi büyük ölçüde kabul edilmektedir (Krefting, 1991). Bu durum, nitel çalışmalarda niteliği ölçmek için bir çabanın olmadığı anlamına gelmemektedir. Aksine; niteliğin ve sağlamlığın arttırılması için pek çok farklı yöntem, teknik ve strateji geliştirilmektedir (Gioia, Corley, ve Hamilton, 2013; Guba ve Lincoln, 1982; Tracy, 2010). Bu süreç pek çok farklı kavramın da ortaya çımasını sağlamıştır. Önerilen bu farklı ölçütleri inceleyen Whittemore vd. (2001), nitel araştırmalarda niteliği ölçen kriterleri; inandırıcılık, otantiklik, eleştirellik, iç bütünlük, açılık, canlılık, yaratıcılık, detaycılık, uyumluluk ve duyarlılık olarak sıralamıştır. Yine geçerlik/güvenirlik ya da Guba ve Lincoln'ün (1982) tanımıyla inandırıcıllğı (trustworthiness) arttırmak için ise uzun süreli etkileşim, katılımcı teyidi, çeşitlendirme, amaçlı örneklem, dışardan araştırmacı denetimi, ortamın ve katılımcıların ayrıntılı tanıtımı gibi pek çok strateji izlenmektedir (Başkale, 2016). Ger' e (2009) göre nitel araştırmaların sağlamlığını oluşturan üç ana unsur bulunmaktadır. Bunlardan birincisi olan kuram-veri 
diyaloğunda, araştırmacıların gözlemledikleri verileri tekrar tekrar kuramlar açısından düşünerek yorumlaması, verilerden kurama ve literatüre, ardından tekrar verilere gitmesi ve bu döngüyü gerektiği kadar yinelemesi gerekmektedir. Bir diğer unsur olan eleştirel farkındalıkta ise gözlemci kendi beklenti, önyargı ve faraziyelerinin bilincinde olarak; bunların, yapılan araştırma üzerindeki etkilerini kavrayabilmeli ve tedbir alabilmelidir. Geçerli ve güvenilir sonuçlar elde etmenin ise birden çok alt başlığı bulunmaktadır. Öncelikle gözlemci sahaya yakın ve hâkim olmalıdır, üstelik bunu okuyucuya açıklayabilmelidir. Daha önce de ifade edildiği gibi hem veri kaynaklarında hem de örneklemde çokluk ve çeşitlilik ilkesi benimsenmelidir. Bununla birlikte, veri çözümlemede de çokluk ve çeşitlilik stratejisi izlemek çalışmaların niteliğini arttıracaktır.

\section{YÖNTEM}

Araştırmanın asıl amacl; ulusal yazında yer alan, pazarlama disiplini içerisinde yayınlanmış nitel çalışmaların incelenmesidir. İkincil olarak nitel araştırmalarda karşılaşılabilecek sorunlar ile çözümleri irdelenecek ve bu amaç doğrultusunda seçilen makalelerden yararlanılacaktır. Bu nedenle araştırmanın kapsamı, pazarlama alanına odaklanmış ve bu alan içerisinde makaleler yayınlayan dergiler ile sınırlandırılmıştır. Bu doğrultuda karşılaşılan dergiler; Pazarlama ve Pazarlama Araştırmaları Dergisi (PPAD), Tüketici ve Tüketim Araştırmaları Dergisi (TTAD), Pazarlama Teorisi ve Uygulamaları Dergisi (PATU), Girişimcilik İnovasyon ve Pazarlama Araştırmaları Dergisi (GIMAD), Pazarlama İçgörüsü Üzerine Çalışmalar (SOMI), Güncel Pazarlama Yaklaşımları ve Araştırmaları Dergisi (PYAD) olmuştur. Bu dergilerin en eskilerinin yayın hayatı 2008 yılına kadar gitmektedir. Dergi yaşlarının çok eski tarihlere kadar uzanmaması sebebiyle herhangi bir yıl sınırlaması yapılmasına gerek duyulmamıştır. İlgili makaleler 07.05.2020 tarihinde dergipark.gov.tr'den indirilmiştir. Seçilen dergilerin ilk sayılarından son sayılara kadar yayınladıkları tüm makaleler metodolojik olarak incelenmiş olup nicel veya karma yöntem kullanan makaleler analiz dışı bırakılmıştır. Bununla birlikte ampirik olmayıp yalnızca kavramsal tartışmalar yürüten çalışmalar ve değerlendirme çalışmaları da bu araştırmanın kapsamı dışındadır. Bu elemeler yapıldıktan sonra seçilen dergiler içerisinde 33 nitel çalışma ile karşılaşılmaktadır. Çalışmalar öncelikle yayınlandıkları dergi, yıl ve araştırma konularına göre, ardından ise araştırma deseni (vaka analizi, olgubilimsel yaklaşım, vb.), kullanılan strateji/teknik/analiz (içerik analizi, semiyotik analiz, tematik analiz vb.) ve veri toplama yöntemine (görüşme, doküman vb.) göre içerik analizine tabi tutulmuştur.

Tablo 1: Yıl, dergi ve temalara göre incelenen makaleler

\begin{tabular}{|c|c|c|c|}
\hline No & Makale & Dergi & Anahtar Kelime \\
\hline 1 & $\begin{array}{l}\text { (Özbakır ve Velioğlu, } \\
\text { 2010) }\end{array}$ & TTAD & Sürdürülebilirlik, Sürdürülebilir Pazarlama, Örnek Olay Analizi \\
\hline 2 & $\begin{array}{l}\text { (De Kervenoael, Koçoğlu, } \\
\text { Uğurlu, ve Bozkaya, } \\
\text { 2011) }\end{array}$ & PPAD & $\begin{array}{l}\text { E-Perakendecilik, Lojistik, Kentsel Planlama, Gelişen Pazar, } \\
\text { Direnç Stratejileri }\end{array}$ \\
\hline 3 & (Altuntaş ve Tuna, 2012) & PPAD & Lojistik Merkez, Endüstriyel Satın Alma \\
\hline 4 & (Tufan ve Özdil, 2012) & PPAD & Pazarlama İletişimi, Radyo Yayıncılığı, Kurumsal İmaj \\
\hline 5 & (Bozkurt ve Ergen, 2012) & PPAD & $\begin{array}{l}\text { Mobil Pazarlama, } 2 \text { Boyutlu Barkodlar, Mobil Etiketleme, QR } \\
\text { Kodlar }\end{array}$ \\
\hline 6 & (Koçak ve Karaca, 2013) & PPAD & $\begin{array}{l}\text { Kaynak Temelli Yaklaşım, Örgütsel Karakteristikler, Yenilik, } \\
\text { Yenilik Kapasitesi, Yenilik Yönetimi }\end{array}$ \\
\hline 7 & $\begin{array}{l}\text { (Bulut, Tekinbaş, ve } \\
\text { Babacan, 2014) }\end{array}$ & TTAD & $\begin{array}{l}\text { Okul Öncesi Yaş Grubu, Pazarlama Kavramları, Farkındalık, } \\
\text { Drama Yöntemi }\end{array}$ \\
\hline
\end{tabular}


M. A. Tiltay - A. Akpınar 13/1 (2021) 994-1015

\begin{tabular}{|c|c|c|c|}
\hline 8 & $\begin{array}{l}\text { (Bardakc1 ve Akınc1, } \\
\text { 2014) }\end{array}$ & TTAD & Markalama, Yabancı Dil, Taklit Teorisi \\
\hline 9 & $\begin{array}{l}\text { (Kacar, Kartal, ve } \\
\text { Kahraman, 2014) }\end{array}$ & PPAD & $\begin{array}{l}\text { Sosyal Pazarlama, Çevreci Sivil Toplum Kuruluşları, Kampanya } \\
\text { Yönetimi }\end{array}$ \\
\hline 10 & (Başfırıncı, 2015) & TTAD & Türk Atasözleri, Alışveriş, Tüketim, Kültür, Tüketim Kültürü \\
\hline 11 & $\begin{array}{l}\text { (Karababa ve Kjeldgaard, } \\
\text { 2015) }\end{array}$ & TTAD & Marka Değeri, Global Ticaret Ağları, Pazar Antropolojisi \\
\hline 12 & (Avan ve Özdemir, 2015) & TTAD & Hizmet Pazarlaması, Fiziksel Unsurlar, Etkileşim \\
\hline 13 & (Cengiz ve Başaran, 2016) & TTAD & $\begin{array}{l}\text { Netnografi, Tüketici Yorumları, Tüketici Tecrübesi, Online } \\
\text { Alışveriş }\end{array}$ \\
\hline 14 & (Atakan ve Seraj, 2016) & PPAD & $\begin{array}{l}\text { Tüketici Davranışı, Ev Yapımı, Yemek Hazırlama, Tüketici } \\
\text { Motivasyonu, Üretici Tüketici Kültürü, Nitel Araştırma, } \\
\text { Netnografi }\end{array}$ \\
\hline 15 & (Farina ve Arslan, 2016) & PPAD & $\begin{array}{l}\text { Ülke Markası, Ülke İmajı, Ulus Markası, İmaj Yönetimi, Türkiye, } \\
\text { Birleşik Krallık, Avrupa Birliği, İçerik Analizi }\end{array}$ \\
\hline 16 & (Özdemir ve Özer, 2016) & PPAD & $\begin{array}{l}\text { Siyasal Pazarlama, Bütünleşik Pazarlama İletişimi, Algilanan } \\
\text { Toplum, Seçim Afişleri, Göstergebilimsel Çözümleme, } 30 \text { Mart } \\
2014 \text { Yerel Seçimleri }\end{array}$ \\
\hline 17 & (Sabah, 2017) & TTAD & Benlik, Sanal Benlik, Avatar, Tüketim, Sahiplikler \\
\hline 18 & (Çavuşoğlu ve Atik, 2017) & PPAD & $\begin{array}{l}\text { Moda Blogları, Aktör-ağ Teorisi, Tüketici Kaynaklı Pazarlar, } \\
\text { Web 2.0, Blogosphere }\end{array}$ \\
\hline 19 & (Kırcova ve Köse, 2017) & PPAD & $\begin{array}{l}\text { Ürün Yerleştirme, Nitel Araştırma, Ürün Yerleştirmeye Yönelik } \\
\text { Tutumlar, Televizyon Dizileri ve Filmlerde Ürün Yerleştirme }\end{array}$ \\
\hline 20 & (Coşkun, 2018) & SOMI & $\begin{array}{l}\text { Elektronik Atık, Cep Telefonu, Genişletilmiş Üretici } \\
\text { Sorumluluğu, İçerik Analizi }\end{array}$ \\
\hline 21 & (Karayün ve Uca, 2018) & SOMI & $\begin{array}{l}\text { Çevrimiçi Müşteri Portalı, E-Lojistik, Teknoloji, Yük } \\
\text { Operasyonları }\end{array}$ \\
\hline 22 & $\begin{array}{l}\text { (İşçioğlu ve Yurdakul, } \\
\text { 2018) }\end{array}$ & PATU & $\begin{array}{l}\text { İkinci El Giyim Motivasyonları, Moda, Moda Yenilikçiliği, } \\
\text { Sürdürülebilirlik }\end{array}$ \\
\hline 23 & $\begin{array}{l}\text { (Kıymalıoğlu ve Öztürk, } \\
\text { 2018) }\end{array}$ & TTAD & Reklam Etiği, Hassas Tüketiciler, Bebek Maması, TV Reklamları \\
\hline 24 & (Köz ve Atakan, 2018) & PPAD & $\begin{array}{l}\text { Reklamcılık, Dijital Medya, Geleneksel Medya, Zaltman Metafor } \\
\text { Çıkarım Tekniği, Derinlemesine Görüşme }\end{array}$ \\
\hline 25 & (İşçioğlu, 2018) & PPAD & $\begin{array}{l}\text { Sanal Market Alışverişi, Hızlı Tüketim Malları, Satın Alma } \\
\text { Niyeti, Sürekli İlgilenim, Güven }\end{array}$ \\
\hline
\end{tabular}


M. A. Tiltay - A. Akpinar 13/1 (2021) 994-1015

\begin{tabular}{|c|c|c|c|}
\hline 26 & $\begin{array}{ll}\text { (Çelebi } & \text { ve } \\
\text { Bayrakdaroğlu, 2018) }\end{array}$ & GIPAD & Tüketici Davranışları, Y Kuşağı, Bilinçli Tüketim \\
\hline 27 & (İşlek ve Erdoğan, 2019) & TTAD & Anadolu Yaklaşımı, Girişimci Biyografileri, Pazarlama Teorisi \\
\hline 28 & (Çelik, 2019) & TTAD & Nefret, Marka Nefreti, Taraftarlık, Ankaragücü, Beşiktaş \\
\hline 29 & $\begin{array}{l}\text { (Giritlioğlu, Tan, Sürme, } \\
\text { ve Akmaz, 2019) }\end{array}$ & PPAD & $\begin{array}{l}\text { Yiyecek-İçecek İşletmeleri, Tüketici Yorumları, Gaziantep, } \\
\text { Foursquare }\end{array}$ \\
\hline 30 & (Y. Arslan, 2019) & TTAD & $\begin{array}{l}\text { Gıda Tüketimi, Kanaat Önderleri, Tüketici Sağlığı, Sağlık } \\
\text { İletișimi, Canan Karatay }\end{array}$ \\
\hline 31 & $\begin{array}{l}\text { (Açıalın ve Kayabaşı, } \\
\text { 2019) }\end{array}$ & PATU & $\begin{array}{l}\text { Sürdürülebilir İnovasyon, Sürdürülebilirlik Pazarlaması, } \\
\text { Yenilik, Kaynak Temelli Yaklaşım }\end{array}$ \\
\hline 32 & (Dalgıç ve Tiltay, 2019) & PATU & Otomotiv Sektörü, Marka Bağlılığı, Tüketici Tipolojileri \\
\hline 33 & (Z. Arslan, 2019) & PPAD & $\begin{array}{l}\text { Kurumsal Marka, Kurumsal Sürdürülebilirlik, Sürdürülebilir } \\
\text { Kurumsal Marka, Kurumsal Teori, Meşruluk }\end{array}$ \\
\hline
\end{tabular}

Makalelerin \%80'den fazlasının, yayın hayatına sırasıyla 2008 ve 2009 yıllarında başlamış olan Pazarlama ve Pazarlama Araştırmaları Dergisi ile Tüketici ve Tüketim Araştırmaları Dergilerinde yayınlandığı görülmektedir. Diğer dergilerin daha yakın dönemde yayın hayatına başlamaları nedeniyle bu dağılım oldukça doğal karşılanabilir. Dergilerden hiçbirisi yöntem olarak nicel ya da nitel tarafa yönelmiş durumda değildir veyahut bunu deklare etmemiştir. Buna rağmen toplam 6 dergide yayınlanan 332 adet makaleden yalnızca 33 tanesinin nitel yöntem kullandığı görülmektedir. İncelenen makale sayısının görece az olması, dergilerin bazılarının çok genç olması sebebiyle uzamsal çıkarsamalar çok fazla şey ifade etmeyecek olsa bile yine de son yıllarda nitel yöntemlerin kullanıldığı makale sayısında gözle görülür bir artış olduğunu söylemek mümkündür. Araştırma konularına bakıldığında ise marka, imaj, tüketici kültürü gibi daha soyut konuların yanı sıra; lojistik, sürdürülebilirlik gibi daha çok nicel ve matematiksel yöntemlerle çalışılan araştırma konuları da göze çarpmaktadır.

\section{BULGULAR}

\section{Nitel Araştırmalarda Yöntem}

Nitel araştırmalar farklı şekillerde yapılabilmekte (Goulding, 1999; Guba ve Lincoln, 1994) ve genel olarak üzerinde uzlaşılmış bir metodoloji bulunmamaktadır. Araştırmacılar nitel araştırmaya başlamadan önce öncelikle hangi ontolojik, epistemolojik aksiyolojik ve metodolojik duruşa sahip olduklarına dair bazı felsefi varsayımlarını gözden geçirmelidirler (Creswell, Hanson, Clark Plano, ve Morales, 2007). Nitel araştırmacılar pozitivist, post-pozitivist, yapılandırmacı, yorumsamacı, eleştirel ve postyapısal gibi farklı paradigmada yer alabilmekte (Denzin ve Lincoln, 2005); üstelik yazım üsluplarıla da makalelerinde bunu hissettirebilmektedirler. Araştırmacılar çalışmalarına büyük bir tasarım seçerek başlayabilirler. Creswell'e göre (2007) beş temel nitel araştırma tasarımı bulunmaktadır: anlatı araştırması, vaka çalışması, gömülü kuram, fenomenoloji ve katılımcı eylem araştırması. Tesch (1990), 28 yaklaşım tanımlamış, Wolcott (2009) ise 22 çeşit araştırma yöntemi belirlemiştir. Marshall ve Rossman (2016), farklı yazarların başlıca stratejiler ile ilgili yaptıkları sınıflandırmaları birlikte incelemiştir (Tablo 2). Bu alternatifleri birbirinden ayıran noktaları ise veri toplama stratejileri ve veri analizi prosedürlerinin birbirinden farklı olmasıdır.

Tablo 2: Nitel araştırmalarda kullanılan stratejiler 
M. A. Tiltay - A. Akpinar 13/1 (2021) 994-1015

\begin{tabular}{|c|c|c|c|c|}
\hline (Jacob, 1987) & $\begin{array}{l}\text { (Atkinson, } \\
\text { Delamont, ve } \\
\text { Hammersley, } \\
\text { 1988) }\end{array}$ & (Patton, 2002) & $\begin{array}{l}\text { (Denzin ve } \\
\text { Lincoln, 2005) }\end{array}$ & (Creswell, 2013) \\
\hline \multicolumn{5}{|c|}{ Yazarların birbirileriyle örtüştükleri stratejiler } \\
\hline $\begin{array}{l}\text { Bütüncül } \\
\text { etnografi (holistic } \\
\text { ethnography) } \\
\text { Bilişsel } \\
\text { antropoloji } \\
\text { (cognitive } \\
\text { anthropology) }\end{array}$ & $\begin{array}{l}\text { Antropoloji } \\
\text { (antrhopology) } \\
\text { Neo-Marksist } \\
\text { etnografi (neo- } \\
\text { marxist } \\
\text { ethnography) }\end{array}$ & $\begin{array}{l}\text { Etnografi } \\
\text { (ethnography) } \\
\text { Oto-etnografi } \\
\text { (autoethnography) }\end{array}$ & $\begin{array}{l}\text { Etnografi } \\
\text { (ethnography) } \\
\text { Performans- } \\
\text { etnografi } \\
\text { (performance } \\
\text { ethnography) }\end{array}$ & $\begin{array}{l}\text { Etnografi } \\
\text { (ethnography) }\end{array}$ \\
\hline $\begin{array}{l}\text { İletişimsel } \\
\text { etnografi } \\
\text { (ethnography of } \\
\text { communication) }\end{array}$ & $\begin{array}{l}\text { Sosyo-dilbilimsel } \\
\text { (sociolinguistics) }\end{array}$ & $\begin{array}{l}\text { Anlatı araştırması } \\
\text { (narrative inquiry) }\end{array}$ & $\begin{array}{ll}\text { Yaşamöyküsü } & \text { ve } \\
\text { testimonio } & \text { (life } \\
\text { history } & \text { and } \\
\text { testimonio) } & \\
\end{array}$ & $\begin{array}{l}\text { Anlatı araştırması } \\
\text { (narrative inquiry) }\end{array}$ \\
\hline \multirow[t]{3}{*}{$\begin{array}{l}\text { Sembolik } \\
\text { etkileşimcilik } \\
\text { (symbolic } \\
\text { interactionism) }\end{array}$} & $\begin{array}{l}\text { Sembolik } \\
\text { etkileşimcilik } \\
\text { (symbolic } \\
\text { interactionism) } \\
\text { Etnometodoloji } \\
\text { (ethnomethodology) }\end{array}$ & $\begin{array}{l}\text { Fenomenoloji } \\
\text { (phenomenology) } \\
\text { Etnometodoloji } \\
\text { (ethnomethodology) }\end{array}$ & $\begin{array}{l}\text { Fenomenoloji } \\
\text { (phenomenology) } \\
\text { Etnometodoloji } \\
\text { (ethnomethodology) }\end{array}$ & $\begin{array}{l}\text { Fenomenoloji } \\
\text { (phenomenology) }\end{array}$ \\
\hline & & $\begin{array}{l}\text { Gömülü kuram } \\
\text { (grounded theory) }\end{array}$ & $\begin{array}{l}\text { Gömülü kuram } \\
\text { (grounded theory) }\end{array}$ & $\begin{array}{l}\text { Gömülü kuram } \\
\text { (grounded theory) }\end{array}$ \\
\hline & & & $\begin{array}{l}\text { Vaka çalışması } \\
\text { (case study) }\end{array}$ & $\begin{array}{l}\text { Vaka çalışması (case } \\
\text { study) }\end{array}$ \\
\hline \multicolumn{5}{|c|}{ Yazarlara özel araştırma türleri } \\
\hline $\begin{array}{l}\text { Ekolojik psikoloji } \\
\text { (ecological } \\
\text { psychology) }\end{array}$ & $\begin{array}{l}\text { Demokratik } \\
\text { ölçüm (democratic } \\
\text { evaluation) }\end{array}$ & $\begin{array}{l}\text { Ekolojik psikoloji } \\
\text { (ecological psychology) }\end{array}$ & $\begin{array}{l}\text { Tarihsel metot } \\
\text { (historical method) }\end{array}$ & \\
\hline \multirow[t]{2}{*}{$\begin{array}{l}\text { İnsan etolojisi } \\
\text { (human ethology) }\end{array}$} & $\begin{array}{l}\text { Feminizm } \\
\text { (feminism) }\end{array}$ & $\begin{array}{l}\text { Keşifsel araştırma } \\
\text { (heuristic inquiry) }\end{array}$ & $\begin{array}{l}\text { Eylem araştırması } \\
\text { (action research) }\end{array}$ & \\
\hline & & $\begin{array}{lr}\begin{array}{l}\text { Toplumsal yap1 ve } \\
\text { inşacilık }\end{array} \\
\text { construction } \\
\text { constructivism) }\end{array}$ & $\begin{array}{l}\text { Klinik araştırma } \\
\text { (clinical research) }\end{array}$ & \\
\hline
\end{tabular}

Kaynak: Marshall, C., \& Rossman, G. B. (2016). Designing Qualitative Research (Sixth edit). Thousand Oaks: Sage.

Nitel çalışmalarda yazarlar görgül bağlamı tasvir etmeye veya veriyi nasıl topladıklarını anlatmaya çok fazla odaklanırlar. Bu durum bazen veri analiz yöntemlerini göz ardı etmelerine yol açmaktadır (Pratt, Kaplan, ve Whittington, 2020). Araştırmacılar çok nitelikli bir veri toplasalar da bunu nasıl analiz ettiklerini iyi bir biçimde aktaramadıkları sürece çalışmaları şeffaflıktan uzaklaşabilmektedir (Bansal ve Corley, 2011). Aynı nicel araştırmalarda olduğu gibi nitel araştırmalarda da kullanılan tekniklerin nasıl ve niçin kullanıldıklarının açıklanması beklenmektedir. Örneğin ZMET tekniğini uygulayan Köz ve Atakan (2018), analizlerinde niçin bu tekniğe başvurduklarını açıklamışlar ve tüm adımları detaylı bir şekilde anlatmışlardır. İçerik analizi yönteminden yararlanan Dalgıç ve Tiltay (2019) ise metodolojinin adımlarını ve yorumlama süreçlerini detaylı bir biçimde aktarmışlardır. Netnografi yöntemini kullanan ve Türkçe literatürde çok fazla netnografik araştırma olmadığını gözlemleyen Atakan ve Seraj (2016), yöntemle ilgili ayrı başlıklar altında açıklamalarda bulunmuşlardır. Tablo 3 'te yazarların kullandıkları araştırma desenleri, analiz ve veri toplama yöntemleri detaylı olarak verilmiştir.

Tablo 3: Araştırma deseni, kullanılan analiz ve veri toplama yöntemlerine göre incelenen makaleler 
M. A. Tiltay - A. Akpinar 13/1 (2021) 994-1015

\begin{tabular}{|c|c|c|}
\hline No & Makale & $\begin{array}{l}\text { Araştırma Deseni - Strateji - Teknik - Analiz - Veri } \\
\text { Toplama Yöntemi }\end{array}$ \\
\hline 1 & (Özbakır ve Velioğlu, 2010) & Örnek olay analizi, yarı yapılandırılmış görüşme \\
\hline 2 & (De Kervenoael vd., 2011) & Yarı yapılandırılmış görüşme, şekle uydurma stratejisi \\
\hline 3 & (Altuntaş ve Tuna, 2012) & Odak grup, içerik analizi, birebir görüşme \\
\hline 4 & (Tufan ve Özdil, 2012) & Alan araştırması, yarı yapılandırılmış görüşme \\
\hline 5 & (Bozkurt ve Ergen, 2012) & Keşifsel araştırma, görüşme \\
\hline 6 & (Koçak ve Karaca, 2013) & $\begin{array}{l}\text { Örnek olay çalışması, çoklu örnek olay çalışması, görüşme, } \\
\text { doküman incelemesi, anket }\end{array}$ \\
\hline 7 & (Bulut vd., 2014) & $\begin{array}{l}\text { Keşifsel araştırma, yarı yapılandırılmış drama, doğaçlama } \\
\text { drama, gözlem }\end{array}$ \\
\hline 8 & (Bardakcı ve Akıncı, 2014) & İçerik analizi \\
\hline 9 & (Kacar, Kartal ve Kahraman, 2014) & İçerik analizi \\
\hline 10 & (Başfırıncı, 2015) & Doküman incelemesi \\
\hline 11 & (Karababa ve Kjeldgaard, 2015) & Vaka analizi, içerik analizi, görüşme \\
\hline 12 & (Avan ve Özdemir, 2015) & $\begin{array}{l}\text { Derinlemesine görüşme, odak grup, betimsel analiz, içerik } \\
\text { analizi }\end{array}$ \\
\hline 13 & (Cengiz ve Başaran, 2016) & Netnografi, Sürekli Karşılaştırma Analizi Yöntemi \\
\hline 14 & (Atakan ve Seraj, 2016) & Netnografi, arşiv verisi, saha notları, \\
\hline 15 & (Farina ve Arslan, 2016) & İçerik analizi \\
\hline 16 & (Özdemir ve Özer, 2016) & Göstergebilimsel analiz \\
\hline 17 & (Sabah, 2017) & Görüşme, odak grup, semiyotik kare analizi \\
\hline 18 & (Çavuşoğlu ve Atik, 2017) & Yarı yapılandırılmış görüşme, içerik analizi, tematik analiz \\
\hline 19 & (Kurcova ve Köse, 2017) & Derinlemesine görüşme, içerik analizi, betimsel analiz \\
\hline 20 & (Coşkun, 2018) & İçerik analizi \\
\hline 21 & (Karayün ve Uca, 2018) & Vaka analizi, görüşme \\
\hline 22 & (İşçioğlu ve Yurdakul, 2018) & $\begin{array}{l}\text { Olgubilimsel yaklaşım, keşifsel araştırma, birebir görüşme, yarı } \\
\text { yapılandırılmış görüşme }\end{array}$ \\
\hline 23 & (Kıymalıŏlu ve Öztürk, 2018) & $\begin{array}{l}\text { Semiyotik Analiz, İdeolojik eleştiri, İçerik analizi, yarı } \\
\text { yapılandırılmış görüşme, Olgubilimsel yaklaşım }\end{array}$ \\
\hline 24 & (Köz ve Atakan, 2018) & ZMET, görüşme \\
\hline 25 & (İşçioğlu, 2018) & Keşifsel araştırma, yarı yapılandırılmış görüşme, içerik analizi \\
\hline 26 & (Çelebi ve Bayrakdaroğlu, 2018) & $\begin{array}{l}\text { Derinlemesine görüşme, yarı yapılandırılmış görüşme, betimsel } \\
\text { analiz }\end{array}$ \\
\hline 27 & (İşlek ve Erdoğan, 2019) & Doküman incelemesi, içerik analizi, keşifsel araştırma tasarımı \\
\hline 28 & (Çelik, 2019) & İçerik analizi \\
\hline 29 & (Giritlioğlu vd., 2019) & İçerik analizi \\
\hline 30 & (Y. Arslan, 2019) & $\begin{array}{l}\text { Tekli örnek olay yöntemi, içsel örnek olay çalışması, içerik } \\
\text { analizi }\end{array}$ \\
\hline 31 & (Açıkalın ve Kayabaşı, 2019) & $\begin{array}{l}\text { Yarı yapılandırılmış görüşme, keşifsel araştırma, çoklu örnek } \\
\text { olay analizi, içerik analizi }\end{array}$ \\
\hline 32 & (Dalgıç ve Tiltay, 2019) & Tekli durum çalışması, gözlem, içerik analizi \\
\hline 33 & (Z. Arslan, 2019) & İçerik analizi, semantik ağ analizi \\
\hline
\end{tabular}

\section{Nitel Çalışmalarda Bağlamın Rolü}

Nitel araştırmaları nicel araştırmalardan ayıran temel noktalardan birisi çalışmanın amacının genellenebilir sonuçlar vermesinden ziyade; derinlemesine birtakım öznel bulgularla teoriye katkı vermesidir (M. G. Pratt vd., 2020). Bu anlamda yazarların bilgiyi bağlama oturtabilmeleri için bir fenomenle ilgili karmaşıklıkları kavrayabilecekleri ortamı ve katılımcıları tercih etmesi gerekmektedir. Bunu yaparken de araştırmacıların çalıştıkları yeri nasıl ve neden seçtiklerini, yani bu görgül bağlamı haklı gerekçelerle açıklamaları beklenmektedir (Welch, Piekkari, Plakoyiannaki, ve Paavilainen-Mäntymäki, 2011). Örneğin marka bağlılı̆̆ını hayran topluluğu bağlamında inceleyen Dalgıç ve Tiltay (2019), Toyota Türkiye hayran topluluğunun 


\section{A. Tiltay - A. Akpinar 13/1 (2021) 994-1015}

çevrimiçi sayfasını analiz birimi olarak belirlemişlerdir. Nedenini ise yüksek miktarda paylaşım yapmaları, çok sayıda üye ve ortak paydalarının büyüklüğü olarak gerekçelendirmişlerdir. Benzer şekilde marka nefreti kavramını taraftarlık bağlamında ele alan Çelik (2019), sosyal medya hesaplarının taraftarlarca marka karşıtı dilin önemli bir inşa alanı olduğunu belirtmişler ve taraftar gruplarının Facebook sayfalarını incelemişlerdir. Tüketim, sahiplikler ve benlik kavramlarını sanal dünya bağlamında inceleyen (Sabah, 2017), söz konusu oyunlarda (MMORPG) yer alan, karakter oluşturma ve geliştirmesine bağlı olarak bu oyunu oynayanlarla görüşme gerçekleştirmişlerdir. Özdemir ve Özer' in (2016) örneklem seçimini nasıl gerekçelendirdikleri, Farina ve Arslan'ın (2016) örneklem seçerken başka uzmanların görüşlerinden nasıl yararlandıkları yine bu başlıkta verilebilecek örneklerdendir. Sonuç olarak bağlam, nitel çalışmaları şekillendirmede önemli bir yere sahiptir ve araştırmacıların araştırdıkları konuyla ilgili görgül bağlamları neden tercih ettiklerini açıklamaları beklenmektedir (Crick, 2020).

\section{Nitel Çalışmalarda Araştırma Evreni, Örneklem ve Veri Toplama}

Nitel araştırmalar nicel araştırmalarla karşılaştırıldığında genellikle çok daha küçük örneklemlerle yapılmaktadır. Nitel araştırmalarda küçük bir örneklemden zengin bulgular elde edebilmek amaçlanmaktadır (Goulding, 1999). Nitel örneklemede çalışmayı en iyi şekilde bilgilendirebilecek olan uygun katılımcıların belirlenmesi gerekmektedir. Nitel veride katılımcı sayısı az olsa bile görüşmelerin süresinin uzatılması ya da birden fazla veri kaynağından bilgi elde edilmesi ile toplam veri zenginleştirilebilmektedir. Bazı araştırmacılar doygunluk olarak adlandırdıkları (Charmaz, 2014), ortaya çıkan temalar tamamen geliştirilinceye kadar veri toplanmaya devam edilen bir tekniği savunmaktadırlar (Fossey, Harvey, McDermott, ve Davidson, 2002). Doygunluk sağlandığı durumda, artık elde edilen taze veriler yeni teorik içgörülere yol açmaz ve veri toplama işi bırakılır. Örneğin Atakan ve Seraj (2016), netnografi yöntemini kullandıkları araştırmalarında, yedi senelik bir zaman dilimini kapsayan süreç içerisinde 2000 yorum içeren bir veri setinden yararlanmışlardır. İlk 1000 veri toplandıktan sonra analiz sürecine başlanmış ve temaların teorik doyuma ulaşması sonucunda 2000 sayısına ulaştıklarında veri toplanmasına son vermişlerdir. Açıkalın ve Kayabaşı (2019) da tekrarlayan ifadelerin artmasıyla beraber verilerinin doygunluğa ulaştığını belirtmişlerdir. Ancak doygunluk pek çok faktöre bağlı olabilmekte ve bunlardan bazıları araştırmacıların kontrolü dışında meydana gelebilmektedir. Örneğin; görüşülen kişilerin ne kadar homojen veya heterojen olduğu ya da araştırmacının konuyla ilgili deneyimi gibi problemler ortaya çıkabilmektedir.

Nitel araştırmalar üzerine literatüre genel itibariyle bakıldığında yapılan görüşmelerde 5 ila 50 arasında katılımcının önerildiği görülmektedir (Dworkin, 2012). Vaka çalışmalarında en az iki farklı vakanın yer alması gerektiği (Guest, Bunce, ve Johnson, 2006) gibi görüşler yer alsa da bazı durumlarda tek bir vakanın da teoriye katkı yapması oldukça mümkün gözükmektedir (Boddy, 2016). Örneğin Arslan (2019), kanaat önderlerinin tüketicilerin gıda tüketimlerini ne şekilde şekillendirdiğini incelediği çalışmasında, başlangıçta 10 farklı kanaat önderi çerçevesinde çoklu örnek olay stratejisi tasarlasa da araştırmaya başladıktan sonra Canan Karatay'ın bu konuda çok fazla ön plana çıktığını görmüş ve konunun daha derin ve ayrıntılı anlaşılabilmesi adına tekli örnek olay çalışması yapmaya karar vermiştir. Lincoln ve Guba'ya (2000)'ya göre ise nitel araştırmalarda örneklem büyüklüğü tartışmaları pozitivizmin izleridir ve nitel araştırmacılarca reddedilmelidir. Burada belirtilmesi gereken bir başka husus ise Kuzey Amerikalı yazarların daha fazla örneklem büyüklüğünü savunduklarıdır (B. Marshall, Cardon, Poddar, ve Fontenot, 2013). Örneğin Boddy, Amerikan bir araştırmacının, çalışmasında yaklaşık 1000 derinlemesine görüşme yaptığını aktarmıştır (Boddy, 2016). Creswell'in (2007) gözden geçirdiği pek çok nitel çalışmaya göre; anlatı araştırmalarında bir veya iki, fenomenolojide üç ila on, kuram oluşturmada ise yirmi ila otuz kişiyle görüşmek yeterli görülmektedir. Özetle, örneklem büyüklüğünü belirlemek nitel araştırmalar için halen tartışmalı bir konudur (Dworkin, 2012). Aşağıdaki tabloda incelenen araştırmaların örneklemleri görülmektedir:

Tablo 4: Araştırmaların örneklemleri

\begin{tabular}{|l|l|l|}
\hline No & Makale & Örneklem \\
\hline 1 & (Özbakır ve Velioğlu, 2010) & $\begin{array}{l}\text { Bir işletmenin pazarlama ve reklam müdürü ve ürün genel } \\
\text { müdür yardımcısı ile görüşülmüştür. Ayrıca işletmenin raporları } \\
\text { incelenmiştir. }\end{array}$ \\
\hline
\end{tabular}


M. A. Tiltay - A. Akpinar 13/1 (2021) 994-1015

\begin{tabular}{|c|c|c|}
\hline 2 & (De Kervenoael vd., 2011) & $\begin{array}{l}15 \text { e-perakendeci, } 7 \text { lojistikçi ve } 7 \text { kentsel planlamacı toplamda } 29 \\
\text { uzman ile mülakat. }\end{array}$ \\
\hline 3 & (Altuntaş ve Tuna, 2012) & $\begin{array}{l}\text { Lojistiğin farklı faaliyetlerini temsil eden } 5 \text { katılımcı. } 5 \text { farklı } \\
\text { lojistik dergisi. }\end{array}$ \\
\hline 4 & (Tufan ve Özdil, 2012) & $\begin{array}{l}4 \text { radyonun yayın yönetmenleri ve pazarlama yöneticileri ile } \\
\text { görüşülmüştür. }\end{array}$ \\
\hline 5 & (Bozkurt ve Ergen, 2012) & $\begin{array}{l}10 \text { uzman ile görüşme gerçekleştirilmiş ayrıca ikincil veri olarak } \\
\text { makaleler ve internet sitelerinden yararlanılmıştır. }\end{array}$ \\
\hline 6 & (Koçak ve Karaca, 2013) & $\begin{array}{l}\text { Beş farklı sektörden toplamda } 55 \text { tane işletmenin departman } \\
\text { yönetici ile görüşülmüştür. Ayrıca işletmelerle ilgili belgeler de } \\
\text { incelenmiştir. }\end{array}$ \\
\hline 7 & (Bulut vd., 2014) & 32 katılımcı ile görüşülmüştür. \\
\hline 8 & (Bardakcı ve Akınc1, 2014) & 4000 markanın kelime kökeni incelenmiştir. \\
\hline 9 & $\begin{array}{l}\text { (Kacar, Kartal ve Kahraman, } \\
\text { 2014) }\end{array}$ & 25 kampanya incelenmiştir. \\
\hline 10 & (Başfırıncl, 2015) & 118 atasözü incelenmiştir. \\
\hline 11 & (Karababa ve Kjeldgaard, 2015) & $\begin{array}{l}\text { İşletmeyle alakalı } 3 \text { farklı aktörle görüşme gerçekleştirilmiştir. } \\
\text { Ayrıca işletmenin web sayfası incelenmiştir. }\end{array}$ \\
\hline 12 & (Avan ve Özdemir, 2015) & $\begin{array}{lccccc}\begin{array}{l}\text { Farklı gruplardan } \\
\text { gerçekleştirilmiştir. }\end{array} & \text { toplamda } & 27 & \text { kişi } & \text { ile } & \text { görüşme } \\
\end{array}$ \\
\hline 13 & (Cengiz ve Başaran, 2016) & $\begin{array}{l}\text { Üç farklı alışveriş sitesinde yer alan } 2500 \text { yorum incelenmiş, } 337 \\
\text { yorum seçilmiştir. }\end{array}$ \\
\hline 14 & (Atakan ve Seraj, 2016) & 4 farklı web-sitesi ve 2000 yorum. \\
\hline 15 & (Farina ve Arslan, 2016) & $\begin{array}{l}\text { Dört ulusal Birleşik Krallık gazetesinde yer alan } 1081 \text { haber } \\
\text { incelenmiştir. }\end{array}$ \\
\hline 16 & (Özdemir ve Özer, 2016) & Üç büyük partinin toplamda 39 afişi incelenmiştir. \\
\hline 17 & (Sabah, 2017) & Sekiz dijital oyun kullanıcısı ile odak grup görüşmesi yapılmıştır. \\
\hline 18 & (Çavuşoğlu ve Atik, 2017) & $\begin{array}{l}19 \text { moda blogcusu ile görüşülmüştür. Katılımcıların blog sayfaları } \\
\text { ayrıca incelenmiştir. }\end{array}$ \\
\hline 19 & (Kırcova ve Köse, 2017) & 14 katılımcı ile görüşülmüştür. \\
\hline 20 & (Coşkun, 2018) & 11 adet cep telefonu üreticilerinin web-siteleri incelenmiştir. \\
\hline 21 & (Karayün ve Uca, 2018) & $\begin{array}{l}\text { E-ticaretten sorumlu yönetici (1) ile yüz yüze görüşme } \\
\text { yapılmıştır. Ayrıca firmanın internet sitesi, görsel medya, internet } \\
\text { ve işletmenin arşivleri kullanılmıştır. }\end{array}$ \\
\hline 22 & (İşçioğlu ve Yurdakul, 2018) & 20 adet tüketici ile birebir mülakat gerçekleştirilmiştir. \\
\hline 23 & (Kiymalığlu ve Öztürk, 2018) & $\begin{array}{l}2 \text { televizyon reklamı incelenmiştir. Toplamda } 14 \text { katılımcı ve } 5 \\
\text { uzman ile görüşme gerçekleştirilmiştir. }\end{array}$ \\
\hline 24 & (Köz ve Atakan, 2018) & 12 tüketici ile görüşülmüştür. \\
\hline 25 & (İşçioğlu, 2018) & 38 katılımcı ile mülakat gerçekleştirilmiştir. \\
\hline 26 & (Çelebi ve Bayrakdaroğlu, 2018) & Toplamda 6 katılımcı görüşülmüştür. \\
\hline 27 & (İşlek ve Erdoğan, 2019) & 16 adet biyografik ve otobiyografik eser \\
\hline 28 & (Çelik, 2019) & Taraftarların kurduğu 4 farklı sosyal medya sayfası. \\
\hline 29 & (Giritlioğlu vd., 2019) & $\begin{array}{l}90 \text { adet işletmenin sosyal medya hesabının altında yer alan } \\
\text { yorumlar. Toplamda } 779 \text { yorum incelenmiştir. }\end{array}$ \\
\hline 30 & (Y. Arslan, 2019) & $\begin{array}{l}\text { Farklı platformlarda yer alan toplamda } 512 \text { adet yorum } \\
\text { incelenmiştir. }\end{array}$ \\
\hline 31 & (Açıkalın ve Kayabaşı, 2019) & $\begin{array}{l}\text { Üç farklı işletmenin üst düzey yöneticisi ile görüşülmüştür. } \\
\text { Ayrıca işletmelerin raporlar ve web sayfaları incelenmiştir. }\end{array}$ \\
\hline 32 & (Dalgıç ve Tiltay, 2019) & Yaklaşık 3000 tane yorum incelenmiştir. \\
\hline 33 & (Z. Arslan, 2019) & 11 firmanın sürdürülebilirlik raporları incelenmiştir. \\
\hline
\end{tabular}

Örneklem seçiminde kullanılan temel stratejilerden birisi amaçlı örneklem tasarımıdır (Örneklem stratejilerinin detaylı incelemesi için: Kuzel, 1999). Örneğin, İşçioğlu ve Yurdakul (2018), sayılarının az olması 


\section{A. Tiltay - A. Akpinar 13/1 (2021) 994-1015}

ve ikinci el kıyafet alımının genellikle gizli gerçekleşmesi sebebiyle amaçlı örneklem tekniğini kullanmışlardır. Benzer şekilde sık televizyon ve film izleyen tüketicilerle yaptıkları çalışmalarında Kırcova ve Köse (2017), amaçlı örneklem yöntemlerinden birisi olan ölçüt örnekleme tekniğinden yararlanmışlardır. Konu hakkında çeşitli bakış açılarının temsilini en üst düzeye çıkartabilmek için De Kervenoael vd. (2011), e-perakendeciler, lojistikçiler ve kentsel planlamacılarla ayrı ayrı görüşmeler yapmışlar ve daha fazla uzmanla görüşebilmek adına kartopu örneklem tekniğini kullanmışlardır. Benzer ş̧ekilde sanal market alışverişinde durumsal faktörlerin etkisini araştıran İşçioğlu (2018), bu faktörlerin geçerli olduğu tüketicileri bulmanın zorluğu neticesinde kartopu örnekleme yöntemini uygulamıştır. Kısaca bu strateji, kişilere erişilmenin ve yaklaşmanın zor olduğu durumlarda tercih edilmektedir. Hiçbir stratejinin diğerine üstünlüğü bulunmamakla birlikte bu seçimler araştırmanın güvenilirliğini doğrudan doğruya etkilemektedir. Nitel araştırma raporunu okuyanlar için bu kullanılan örnekleme stratejileri açıkça ifade edilmeli ve nedenleri anlatılmalıdır (Fossey vd., 2002).

Örneklemle bağlantılı olan bir diğer konu da nitel araştırmacıların raporlamalarını, genellikle tek bir veri kaynağına bağlı kalarak yapmalarıdır. Örneğin; farklı işletmelerden yalnızca birer çalışanla görüşmek yalnızca bir kişinin perspektifini yansıtacağı için güvenirlik ile ilgili problemlere yol açabilmektedir (Morrow, 2005). Bu durumu aşabilmek için araştırmacılar işletmelerin farklı birimlerinden kişilerle görüşerek çok katmanlı veri elde edilebilmektedir (Welch vd., 2011). Bu uygulamaya örnek olarak, Koçak ve Karaca (2013), farklı firmaların üretim, ar-ge ve pazarlama birimi yöneticileri ile görüşerek yenilik yönetimiyle ilgili farklı birimlerin örgütsel karakteristiklerini yansıtmışlardır. Yine benzer biçimde, Avan ve Özdemir (2015) hizmet ortamı ve kullanıcı etkileşimlerini inceledikleri araştırmalarında otel müşterileri, yöneticiler ve mimarlardan oluşan üç farklı grup ile görüşme yapmışlardır. Ancak araştırmacılar tek bir kaynaktan veri elde etmeyi seçtikleri durumlarda ise bu durumun gerekçelerini iyi bir şekilde anlatabilmelidirler (Healy ve Perry, 2000). Bununla beraber nitel araştırmacılar, her ne kadar işletmelerin arşiv kayıtlarını elde etmek zor olsa da verilerini bazı ikincil verilerle de destekleyerek çok katmanlı hale getirebilirler (Alam, 2005). Örneğin Karababa ve Kjeldgaard (2015), orta düzey yöneticilerle yaptıkları görüşmelerin dışında, firmanın tarihçesiyle ilgili kitap, firma raporları, medyada yer alan köşe yazıları, firmanın Facebook sayfası gibi ikincil verilerle araştırma bulgularını desteklemişlerdir. Bir diğer örnekte görüleceği üzere, Açıkalın ve Kayabaşı (2019) ise çalışmalarında üst düzey yöneticilerle görüşmelerinin haricinde işletmelerin web sayfaları ve faaliyet raporlarını da inceleyerek araştırmanın güvenirliğini arttırmışlardır.

\section{Nitel Araștırmaların Teorik Katkısı ve Literatür Taraması}

Nicel, nitel ya da karma hangi yöntemle yazılırsa yazılsın makaleleri değerli kılan en önemli noktalardan birisi de yazarların literatüre yaptıkları katkıdır (Jonsen, Fendt, ve Point, 2018). Kuram oluşturma ve test etme konusunu inceleyen Colquitt ve Zapata-Phelan (2007), makaleleri katkılarına göre beş kategoride sınıflandırmaktadır: rapor edenler, test edenler, nitelik kazandıranlar, oluşturanlar ve genişletenler. Kuram oluşturanlar, test edenler ve genişletenler teoriye çok daha fazla katkı sağlarken; rapor edenler ve nitelendirenler ise daha düşük katkı vermeye eğilimlidirler. Eğer çalışılan konu teoriye yeni bir şeyler söylemiyorsa, elde edilen verilerin zenginliği, uygulanan yöntemin sağlamlığının çok bir önemi kalmayabilir. Bu anlamda nitel araştırmacılar literatürü hazır modeller ve kavramları almak için değil, kendi kavramlarını geliştirmek amacıyla kullanmalıdırlar (Ger, 2009). Güvenirlik nitel çalışmalarda ne kadar önemliyse nitel araştırmaların teorik katkıları da bir o kadar önemli görülmektedir. Kuramlar nitel araştırmalarda yazarın amacına uygun olarak çalışmanın başlarına ya da sonlarına yerleştirilebilir (Creswell, 2007). Ancak çalışmada yer alan kuram tamamen tümevarım şeklinde kullanılmamalı aksine kuram ve veri sürekli birbiriyle diyalog haline olmalıdır (Ger, 2009). Ortaya çıkan kategori ve temalar ile literatür arasında sürekli bir bağlantı kurularak döngüsel yorumlama sürecini uygulayan araştırmalar (İşçioğlu ve Yurdakul, 2018) burada örnek gösterilebilir. Graeber'in değer teorisini kullanan Karababa ve Kjeldgaard (2015), araştırmalarını kaynak temelli yaklaşım bakış açısına dayandıran Açıkalın ve Kayabaşı (2019), marka bağlılığı kavramını otomobil sektöründe inceleyen Dalgıç ve Tiltay (2019), pazarlamada Kuzey Amerika ve Alp-Germen bakış açılarına bir alternatif olarak Anadolu yaklaşımını öneren İşlek ve Erdoğan (2019), İbn-i Haldun'un taklit teorisini markalamada kullanan Bardakcı ve Akıncı (2014), bu anlamda örnek verilebilecek çalışmalardandır. Diğer taraftan nitel araştırmacılar sorularını hazırlarken (Karayün ve Uca, 2018) veya kodlamalarını oluştururlarken (Açıkalın ve Kayabaşı, 2019; Kaçar vd., 2014) literatürden yararlanabilmektedirler. 


\section{Nitel Araştırmalarda Güvenirlik ve Geçerlik}

Nitel araştırmacıların genel olarak toplayabileceği üç farklı veriden bahsedilebilir (Ger, 2009). Bunlar; bireylerin söylediği sözler, bireylerin davranışları ve bireylerin daha önce yaptıkları ve toplumda iz bıraktığı nesneler, mekanlar, imgeler ve eserlerdir. Çeşitlilik, nitel araştırma tasarımlarının temel bir unsurudur. Çeşitlilikte temel amaç; incelenen alanın çok yönlü görünümünü elde etmek ve bunun için birden fazla birincil ve/veya ikincil kaynağa başvurmaktır (Golafshani, 2003). Ger (2009) bu konuyu aşağıdaki gibi açıklamaktadır:

"Belli bir ortamda tüketicilerin yaptıklarına ve yapmadıklarına, hem o tüketicinin çevresiyle ilişkisine odaklanmamız gerekmektedir. Ayrıca, söylemle eylemin, fisıldananla yüksek sesle söylenenin, sahnede sergilenenle kuliste yapılanın her zaman aynı olmadığını biliyoruz."

Guba ve Lincoln (1985), nitel araştırmalar için güvenirlik ve geçerlik konseptlerini inandırıcılık (trustworthiness) şeklinde kavramsallaştırmış ve inandırıcıllğı sağlamak için bazı kriterler belirlemiştir. Aşağıdaki tabloda nitel araştırmalarda inandırıcılığı arttırabilmek için uygulanan birtakım yöntemler yer almaktadır:

Tablo 4: Nitel Araştırmaların İnandırıcılığı İçin Kullanılan Yöntemler

\begin{tabular}{|l|l|l|}
\hline Geleneksel Kriterler & İnandırıcılık Kriteri & Yöntemler \\
\hline $\begin{array}{l}\text { İçsel geçerlik } \\
\text { (internal validity) }\end{array}$ & İnanılırlık (credibility) & $\begin{array}{l}\text { Katılımcı teyidi (member checks) } \\
\text { Çeşitlilik (triagulation) } \\
\text { Çok seslilik (multivocality) } \\
\text { Bağımsız akran denetimi (peers debriefing) } \\
\text { Sahayla uzun süreli etkileşim (prolonged engagement at a site) } \\
\text { Yeterli referans materyaller (referential adequacy materials) } \\
\text { Israrcı gözlem (persistant observation) }\end{array}$ \\
\hline $\begin{array}{l}\text { Dişsal geçerlik } \\
\text { (external validity) }\end{array}$ & $\begin{array}{l}\text { Aktarılabilirlik } \\
\text { (transferability) }\end{array}$ & $\begin{array}{l}\text { Kuramsal/amaçlı örneklem (theoretical/purposive sampling) } \\
\text { Yoğun tasvir (thick description) }\end{array}$ \\
\hline $\begin{array}{l}\text { Güvenirlik } \\
\text { (reliability) }\end{array}$ & $\begin{array}{l}\text { Güvenilebilirlik } \\
\text { (dependability) }\end{array}$ & $\begin{array}{l}\text { Örtüşen metotlar (use of overlap methods) } \\
\text { Aşamalı mukabele (stepwise replication) } \\
\text { Güvenilir denetim (the dependability audit) }\end{array}$ \\
\hline $\begin{array}{l}\text { Objektiflik } \\
\text { (objectivity) }\end{array}$ & $\begin{array}{l}\text { Onaylanabilirlik } \\
\text { (confirmability) }\end{array}$ & $\begin{array}{l}\text { Çeşitlilik (triangulation) } \\
\text { Düşünümsellik (practicing reflexivity) } \\
\text { Onaylanabilir denetim (the confirmabiilty audit) }\end{array}$ \\
\hline
\end{tabular}

Kaynak: Lincoln, Y. S., \& Guba, E. G. (1985). Naturalistic inquiry. In Naturalistic inquiry. Beverly Hills CA: Sage.

$\mathrm{Bu}$ anlamda nitel araştırmacılar araştırdıkları fenomenle ilgili daha nesnel ve alternatif içgörüler elde edebilmek için görgül verilerini (örneğin, görüşme veya gözlem notlarını) başka birincil veya ikincil (arşiv) kaynaklarıyla karşılaştırmalılardır (Eisenhardt, 1991). Özellikle seçilen araştırma yöntemine bağlı olarak çeşitlilik (triangulation) bir beklenti olabilir. Örneğin vaka çalışmalarında araştırmacıların seçtikleri vakayı ya da vakaları sağlamlaştırmak için veri kaynaklarının bir kombinasyonunu oluşturma ihtimalleri yüksektir (Eisenhardt ve Graebner, 2007). Literatürde vaka çalışması/örnek olay analizi yapan (Açıkalın ve Kayabaşı, 2019; Dalgıç ve Tiltay, 2019; Karababa ve Kjeldgaard, 2015; Koçak ve Karaca, 2013; Özbakır ve Velioğlu, 2010) araştırmaların hemen hepsi doküman incelemesiyle elde edilen bilgileri desteklemişlerdir. Doküman incelemesi yapan Altuntaş ve Tuna (2012) ise çeşitlilik sağlamak amacıyla beş farklı uzmanla görüşme gerçekleştirmişlerdir.

Nitel araştırmacılar elde ettikleri görgül verileri kodladıkları aşamada, ham halde bulunan veriyi temalara ayırarak organize ederler. Bunu yaparken manuel bir şekilde ya da çeşitli bilgisayar programlarıyla yapma imkanları bulunmaktadır. Bir takım yazılımlarla kodlamaları gerçekleştirmek zamandan kazandırsa da daha geleneksel bir yöntem olan manuel kodlama da güvenilir bir teknik olarak kabul görmektedir (Sinkovics ve Alfoldi, 2012). Ancak manuel kodlama yapan yazarlar için örneğin temalara numara, renk ya da kelime atama gibi sağlamlığı arttıracak bazı yöntemler önerilmektedir (Miles, M.B ve Huberman, 1994). Dahası manuel kodlama yöntemiyle hareket eden yazarların daha şeffaf olmaları beklenmektedir (Morrow, 2005). Örneğin 


\section{A. Tiltay - A. Akpinar 13/1 (2021) 994-1015}

Avan ve Özdemir (2015), nitel verilerin kodlamasını üç aşamada gerçekleştirmişler ve bunları oldukça detaylı bir biçimde analiz yöntemi başlığı altında anlatmışlardır. Bazı araştırmacıların ise (Açıkalın ve Kayabaşı, 2019; Atakan ve Seraj, 2016; İşçioğlu ve Yurdakul, 2018) Nvivo gibi yazılım programlarını tercih ettikleri görülmektedir. Nitel araştırmalarda güvenirliği arttırmanın yollarından birisi de elde edilen verileri araştırmacıların ayrı ayrı analiz etmeleri, kodlamaları ve bu kodlamaları karşılaştırarak ilerlemeleridir (Glaser, 1965). Örneğin Avan ve Özdemir (2015), elde ettikleri temaları ve temaları oluşturan kodları her iki araştırmacının ayrı ayrı yaptıkları analizler sonucunda ortaya çıkartmışlar ve bunları tartışarak karşılaştırmışlardır. Benzer süreçler başka araştırmacılar tarafından da uygulanmıştır (Cengiz ve Başaran, 2016; İşçioğlu ve Yurdakul, 2018). Bununla paralel bir biçimde Kırcova ve Köse (2017) ise belirledikleri kategorilerin bağımsız bir araştırmacı tarafından kontrol edilmesini sağlamışlardır.

Nitel araştırmalarda, özellikle de görüşmeler, gözlemler, odak grubu çalışmalarında, araştırmacıların görgül veriyi yorumlarken katılımcıların içgörülerine kendi perspektiflerini katma riskleri her zaman bulunmaktadır (Gummesson, 2005). Bunun için kullanılan paranteze alma tekniğiyle yazarlar kendi kelimeleri yerine doğrudan doğruya katılımcıların söylediklerini makalelerinde sunabilirler (Tosey, Lawley, ve Meese, 2014). Böylece araştırmacılar verilerini sunarken oluşabilecek yanlış yorumlamaları ortadan kaldırabilirler. Ancak bu tasvir edici cümleleri veya kelimeleri neden seçtiklerini, arkasındaki anlamları ve teoriye katkısını mutlaka belirtmek zorundadırlar (Tufford ve Newman, 2012). Örneğin, Çelebi ve Bayrakdaroğlu (2018), yarı yapılandırılmış görüşme ve betimsel analiz yaptıkları çalı̧̧malarında bulgularını sunarken bu teknikten yararlanmışlardır. Derinlemesine görüşme tekniğinden faydalanan Kırcova ve Köse (2017) de benzer şekilde paranteze alma tekniğini kullanmıştır. Sabah (2017), dilbilgisi kurallarına uymak için olsa bile görüşme notlarında değişiklik yapılmaması kuralına dikkat etmiştir. Netnografik inceleme yapan Cengiz ve Başaran (2016) da aynı şekilde tüketici tecrübelerini olduğu gibi makalelerine yansıtmış ve aynı zamanda sürekli teorik anlamda bu örnekleri desteklemişlerdir. Görgül verileri araştırmada sunmanın gelişmiş bir formu da Gioia metodolojisidir (Gioia vd., 2013). Bu metodolojide nitel veriler üç kategori altında sunulmaktadır: birincil kodlar, ikincil kodlar ya da ikincil temalar ve bir araya gelen (kümeleşen) boyutlar. Gioia metodolojisinin özellikle yönetim alanında daha fazla benimsendiği görülmektedir (Jaskiewicz, Combs, ve Rau, 2015).

Nitel araştırmalarda sahaya yakın ve hâkim olmak inanılırlığı arttıran bir diğer önemli koşuldur. Sahayı tanımak için yeterince vakit geçirmek, katılımclara aşina olup belli ölçüde bir güven oluşturmak gerekmektedir (Korstjens ve Moser, 2018). Böylece tüketicilerin yaşadığ 1 dünyaya temas edilir ve onların gerçekliğine vakıf olunur (Ger, 2009). Kıymalıŏglu ve Öztürk (2018), inanılırlığı arttırabilmek için katılımcılarıyla yeterince vakit geçirmiş ve onların konu hakkindeki saklı hislerini anlamaya çalışmışlardır. Dalgıç ve Tiltay (2019) ise öncelikle incelenecek topluluğu 1 ay boyunca dışarıdan gözlemlemişler, sonra topluluğa üye olarak yaklaşık 12 ay süreyle toplulukta zaman geçirmişlerdir.

\section{SONUÇ ve TARTIŞMA}

Pazarlama disiplinini 1960'lardan itibaren teorik ve metodolojik anlamda etkileyen faktörler üç ana başlıkta özetlenmektedir (Webster ve Lusch, 2013). Birincisi, temel sorunların önemi yerine metodoloji ve veriye dayalı analizlere yapılan aşırı vurgudur. Bunun sonucunda dar kapsamlı birtakım dergiler oluşmuş ve pazarlama disiplin olarak farklı kompartımanlara ayrılmıştır. İkinci faktör, mikro ekonomik indirgemecilik ile dar bir paradigmadan tek bir değişken olarak karı optimize etmeye çalışan normatif modellere olan/duyulan aşırı güvendir. Üçüncüsü ise pazarda yalnızca satıcılar üzerine miyop bir odaklanma ile pazarlamanın etkinliği ve etkililiğinin göz ardı edilmesidir (tüketici faydaları, paydaşların çıkarları, toplumsal refah gibi konular). Birinci faktör, doğrudan veya dolaylı olarak ikinci ve üçüncü faktörleri de etkilemektedir. Disiplinin gelişimi izlendiğinde zaman içerisinde metodolojik olarak sağlamlığın (rigor), ilgi-alakaya (relevance) üstün geldiği görülmektedir (Reibstein, Day, ve Wind, 2009). Nicel araştırmalar nesnel, genellenebilir, bilimsel, metodolojik olarak sağlam gibi ifadeleri çağrıştırırken; nitel araştırmalar ise öznel, genellenemez, bilimsel olmama, soyut, açıklayıcı-keşifsel gibi ifadeleri akla getirmeye başlamışır (Korai ve Souiden, 2019). Hatta araştırmacıların metodolojik olarak da kendilerini belli kalıplara soktukları görülmektedir. Bu gibi tanımlamalar ve kategorileştirmeler, yalnızca o yöntem ile incelenebilen konulara odaklanmaya yol açmaktadır. Örneğin; pazarlama disiplini içerisinde kendisini davranış bilimci olarak tanımlayan bir araştırmacı, muhtemelen deneysel yöntemleri ön plana çıkartacak ve yalnızca deneysel yöntemlerle anlaşılamayacak olan daha geniş ekonomik, sosyal ve toplumsal konuları es geçmek zorunda kalacaktır (MacInnis, 2005). Franke ve Mazanec (2006), pazarlama disiplininden akademisyenlerle görüştükleri araştırmalarında altı farklı kimlik 


\section{A. Tiltay - A. Akpinar 13/1 (2021) 994-1015}

belirlemişlerdir. Farklı kimlikler alanda daha fazla bölünmelere yol açıyor olmakla birlikte disiplinin olgunlaştığına da işaret etmektedir. Pazarlama disiplini içerisinde olduğu düşünülen bu metodolojik bölünmelerin çeşitli nedenleri bulunmaktadır. Daha önce de ifade edildiği üzere, yönetim disiplinlerinin meşruiyetini tesis etmek amacıyla bilimsel statü kazanmaya çalışmaları doğa bilimlerinde kullanılan yöntemlerin sosyal bilimlere uyarlanmasıyla sonuçlanmıştır. Pazarlama alanında da benzer süreç; bilimsel meşruiyet kazanma çabası, alanın önde gelen isimlerin (nicel paradigmada yer alan) etkileri ve nitel araştırmacıların metodolojilerini nicel yöntemlere benzetmeye çalışmaları gibi aşamalarla gerçekleşmiştir (Korai ve Souiden, 2019). Örneğin bilimsel meşruiyet kazanma çabası, Journal of Marketing gibi önde gelen dergilerin ilk yıllarındaki yayınlarla, izleyen yıllardaki yayınların farklılığından anlaşılmaktadır (Kumar, 2015). 1950'li y1llardan itibaren $\mathrm{JM}^{\prime}$ de ve pazarlama literatüründe, pazarlama fenomenleri normatif yaklaşımlardan bilim felsefesi anlamında pozitif; yani açıklayıcı yaklaşımlara doğru kaymışır. Fenomenlerin sinıflandırılmasından çok olasılıksal açılamalara ve tanımlayıcı görgül nedensel analizlere doğru genel bir değişim yaşanmıştır (Kerin, 1996). Güçlü metodolojiler ve veri kaynaklarının makaleleri yayınlamada genel bir kriter haline dönüşmesi, disiplinin gelişmesi açısından gerekli ve oldukça faydalıyken; diğer taraftan ise bu durumun pazarlamayı temel sorunları anlamaktan ziyade, metodoloji ve veriye dayalı analize odaklanan dar bir kapsama yönlendirdiği düşünülmektedir (Webster ve Lusch, 2013). 1980'li yıllardan itibaren ise bu baskınlık bir nebze kırılmaya başlanmış ve nitel yöntemler pazarlama alanında daha fazla kullanılır hale gelmiştir. Buna paralel olarak nitel yöntemlere ağırlık veren dergilerin de aynı dönemlerde ortaya çıtığı görülmektedir (Ger, 2009). Sosyal bilimlerde yaşanan paradigma kaymasının pazarlama alanına etkileri kısa süre içerisinde gerçekleşse de uzun vadede nicel paradigmanın hakimiyeti sürmektedir. Ancak sosyal bilimlerde farklı söylemler ve bakış açılarının gelişimi teşvik edilerek çok sesliliğin inşa edilmesi önem taşımaktadır (Abbott, 2001). Zira eleştirel yaklaşımlara kucak açmak, bir disiplinin olgunluğuna işaret eder (Korai ve Souiden, 2019). Gummeson'un (2005) da ifade ettiği gibi teori üretimi daha çok kavramsal ve nitel bir sürecin sonucu iken, teori testi daha çok ampirik ve nicel hipotez testleri ile ilişkilidir. İki araştırma yöntemi birbirine alternatif olarak görülmemeli, birbirinin tamamlayıcısı olarak ele alınmalıdır. Belk'e (2013) göre iki araştırma yöntemi temel olarak dört ana noktada birbirinden ayrılmaktadır. Nitel araştırmalar çok daha detaylı ve zengin bir veri sağlamaktadırlar. Her ne kadar nicel yöntemlerde verinin büyüklüğü çok güçlü istatistiksel tekniklerin kullanımına izin verse de nitel veriler, insanların ve davranışlarının daha zengin bir tasvirini ortaya koyar. Nitel araştırmalar tüketimi ve pazarlamayı bağlamsal olarak açıklamaya çalışmaktadır. Yani nicel araştırmalar tüketicilerin durumsal faktörler, araştırmacı, zaman ve mekân fark etmeksizin aynı şekilde davranışta bulunacaklarını varsaymaktadır. Nitel araştırmalar olabildiğince doğal ortamlarda gerçekleştirilir. Nicel araştırmalarda ise özellikle de deneysel yöntemlerde birtakım değişkenler kontrol ve manipüle edilir. Son olarak nitel araştırmalarda araştırmacı aktif bir rol alır. Verinin kalitesi güven, aşinalık ve uyum gibi faktörlere bağlıdır. Bu bir yandan sübjektiviteyi arttırırken diğer yandan ise daha fazla insan etkileşimi ve ilişkisine izin verir. Pazarlama disiplininin büyük ölçüde insan davranışına, insan algısına ve insan fenomenine dayandığı düşünüldüğünde (Svensson, 2006) nitel araştırmaların kullanımının, yeni perspektifler elde etme açısından neredeyse bir zorunluluk olduğu söylenebilir. Üstelik bu unsurlar, zamanın akışı içerisinde istikrarsız ve dinamik yapıdadırlar; yani anlaşılabilmek için süreç tasarımlarına ihtiyaç duyarlar (Langley, 1999). Pozitivist temele dayanan nicel yöntemlerin sosyal kavram ve olguları, içinde bulunulan durumları tamamen açıklayabilmesi imkânsız görünmektedir (Dedeoğlu, 2002). İstatistiksel bilgiye sahip olmak, sosyal konuları anlamanın yerini tutmaz ve kendi başına bu sorunların nasıl çözüleceğini gösteremez (Schatzki, 2012). Örneğin nicel yöntemler ile bu olguları anlayabilmek için oluşturulan ögeler, beklenen ve istenen bulgulara uymadığı taktirde basitçe analizden çıkartılmaktadır. Bir veya birkaç hatalı 'ifade' kaldırılmazsa çöken modellere nasıl tamamen güvenilebilir? Özetle, burada yapılan ve daha önce yapılmış tartışmalarda anlatılmak istenen, araştırmacıların alet çantalarında yalnızca çekiç olursa etraflarındaki her şeyi çivi olarak görmeye başlayacaklarıdır.

Yapılan çeşitli bibliyografik analizler incelendiğinde, Türkiye'de de metodolojik anlamda durumun çok farklı olmadığı sonucuna ulaşılmıştır (Bakır, 2013; Çatı ve Öcel, 2018; Arı vd., 2009). Bu araştırmada da incelenen 332 adet makaleden 33 tanesinde (yaklaşık \%10) nitel yöntemler kullanıldığı görülmektedir. Bu durum, daha önce de ifade edildiği gibi her ne kadar nitel araştırmalar pazarlama alanında yükselişte olsalar bile halen nicel yöntem ve post-pozitivist paradigmaların alanda ağırlığını koruduğu sonucuyla benzerlik göstermektedir (Hanson ve Grimmer, 2007). Bunun çeşitli sebepleri olduğu düşünülmektedir. İlki, nitel yöntemlere karşı var olan önyargıdır. Yazarların bir bölümünün nitel çalışmalarda kullanılan yöntemlerin sağlamlığına ilişkin 


\section{A. Tiltay - A. Akpinar 13/1 (2021) 994-1015}

şüpheleri ve önyargıları bulunurken; diğer taraftan bazı yazarlarda ise araştırmalarına yeterince kıymet verilmeyeceği düşüncesi oluşmuştur (Pratt, 2008). İkinci olarak, akademik camiada yer alan statü, terfi ya da ilerleme gibi baskılar araştırmacıları baskın teknik ve yöntemleri uygulamaya, en azından anlamaya zorlamaktadır (Hanson ve Grimmer, 2007). Bu durum, nicel yöntemlerin baskınlığının korunmasına yardım etmektedir. Bunların dışında, neden nitel yöntemlerin pazarlama alanında yaygınlaşmadığı sorusunun olası cevapları; nitel araştırmalar hakkında yeterince eğitim alınmaması ya da nitel araştırma yapmanın çok uzun süre alması olabilmektedir (Tucker vd.,1995) .

Bu çalışmanın temelde iki amacı bulunmaktadır. İlk olarak, Türkçe pazarlama yazınında nitel makaleler; bibliyografik bilgilerine (yayınlandıkları dergi, yıl ve araştırma konuları), kullandıkları yöntemlere (araştırma deseni, stratejileri, teknikler ve veri toplama yöntemlerine), ve örneklemlerine göre içerik analizine tabi tutulmuşlardır. Bu yolla araştırmaların kapsamı ve niteliği görülmeye çalışılmıştır. İkinci olarak ise nitel araştırmacıların karşılaştıkları potansiyel sorunlar ile bunların üstesinden gelebilecekleri metotlardan bahsedilmiştir. Çalışmada özellikle incelenen makaleler üzerinden bunlar örneklendirilerek gelecekte nitel araştırma yapmayı düşünen pazarlama alanındaki akademisyenlere ve lisansüstü araştırmacılara veri toplama ve veri analizi süreçlerini nasıl titizlikle yaparak bu sorunların üstesinden gelebilecekleri gösterilmeye çalışılmıştır. Bu amaca ulaşabilmek için mevcut literatürden bazı araştırmalar gözden geçirilmiş ve şu sonuçlara ulaşılmışır: Araştırmalarda büyük bir tasarımla, metodolojisini şekillendiren makale sayısı oldukça azdır. Literatür incelendiğinde, genellikle kullanılan tasarımın vaka çalışmaları olduğu görülmektedir (örn: Açıkalın ve Kayabaşı, 2019; Dalgıç ve Tiltay, 2019; Karababa ve Kjeldgaard, 2015; Koçak ve Karaca, 2013; Özbakır ve Velioğlu, 2010). Diğer bir kullanılan tasarım ise olgubilimsel yaklaşımdır ve iki çalışmada bu desenden yararlanılmıştır (İşçioğlu ve Yurdakul, 2018; Kıymalığlu ve Öztürk, 2018). Ancak etnografi, gömülü kuram ya da anlatı çalışması gibi bazı tasarımların hiç tercih edilmediği dikkat çekmektedir. Yapılan çalışmalarda çok büyük oranda içerik analizinin kullanılmasının yanı sıra, semiyotik analiz (Kıymalıŏlu ve Öztürk, 2018; Sabah, 2017), semantik ağ analizi (Z. Arslan, 2019), ZMET (Köz ve Atakan, 2018), göstergebilimsel analiz (Özdemir ve Özer, 2016), betimsel analiz (Avan ve Özdemir, 2015; Kırcova ve Köse, 2017), netnografi (Atakan ve Seraj, 2016; Cengiz ve Başaran, 2016) gibi yöntemlerin de kullanıldığı görülmektedir. Veri toplama yöntemlerinde ise araştırmacıların sıklıkla, görüşmeler, doküman incelemeleri zaman zaman da gözlemlerden yararlandıkları sonucuna ulaşılmışır.

Araştırmalarda genel anlamda hem kullanılan yöntemler hem de veri toplama teknikleri açısından bir zenginlik sorunu olduğu görülmektedir. Karşılaşılan bir başka problem ise araştırmacıların veri toplama yöntemlerini araştırmanın kendisi olarak tasvir etmeleridir. Oysa Belk'in de ifade ettiği gibi (Belk, Sherry ve Wallendorf, 1988), nitel yöntemler birtakım insanlarla konuşup söylenenleri kâğıda yazmaktan ibaret değildir. Naturalistik araştırmalar (naturalistic inquiry research) belli bir öğrenme ve tecrübe sonucu uygulanabilmektedir. Aslında nitel araştırmaların genel itibariyle anket ve deneysel yöntemlere kıyasla öğrenilmesi ve uygulanması daha fazla zaman ve sabır istemektedir. Ancak nitel yöntemlerin görece yeni ve az bilinen yöntemler olması dolayısıyla bazı metodolojik hataların ortaya çıkması doğal karşılanmalıdır (Arı vd., 2009). Bu gibi durumların diğer disiplinlerde olduğu gibi pazarlama disiplini içerisinde de zaman içerisinde aşılması beklenmektedir. Bunun için pazarlama dergilerinin Academy of Management Journal örneğinde görüldüğü üzere (Pratt, 2009) alan editörlerine birtakım ipuçları ve önerilerin yer aldığı makaleler yayınlatmaları faydalı olabilir. Zira Pratt'ın (2008) yaptığı araştırmaya göre hakemlerin ve editörlerin en çok eleştirdikleri konular; yöntemin açıklanmaması ya da yetersiz anlatımı, analizin açıklanmaması ya da yetersiz anlatımı, teoriye yeterince katkı yapılmaması ve veriyi yorumlama/gösterme dengesinin ayarlanamamasıdır. Aynı çalışmada nitel araştırmacıların yaşadıkları sorunlar ise; değerlendirme standartlarının olmaması, standartların çok yüksek olması veya standartların uygunsuz olması olarak özetlenmiştir. Bu gibi durumların aşılabilmesinin yollarından biri, bu tür makalelerin yaygınlaşması olabilir. Örneğin TTAD, ilk sayısında Ger'in (2009) buna benzer bir makalesine yer vermiştir. Özellikle genç araştırmacıların, bu noktada üst düzey dergilerin standartlarını karşılayacak seviyeye ulaşabilmeleri için editöryel makaleleri gözden geçirmeleri faydalı olacaktır. Örneğin Epp ve Otnes'in (2020) hazırladıkları yüksek kalitede nitel araştırma yapılırken kullanılacak kontrol listesi (ve örnek makaleler) gibi pek çok başka kapsamlı öneri de literatürde bulunmaktadir.

Görüldüğü üzere nitel araştırmalarda güvenirlik ve geçerlik gibi sorunların çözülebilmesi için pek çok farklı yöntem, teknik ve strateji geliştirilmiştir. Nitel araştırmaların niteliğini arttırmak, zaman içerisinde belli 
önyargıların da kırılmasına ve pazarlama alanında daha da yaygınlaşmasına imkân tanıyacaktır. Nitel yöntemlerin benimsenmesi, araştırmacıların yeni anlayışlar ortaya çıkarmasına ve var olanı farklı yollarla görmelerine olanak tanımaktadır. Dar bir nitel yöntem kümesine odaklanmak, araştırmacılar olarak ortaya çıkarttığımız içgörü türlerini de sınırlamaktadır (Bansal, Smith, ve Vaara, 2018). Yani bir fenomenin anlaşılabilir duruma gelebilmesi için kullanılan yöntemlerin zenginleştirilmesi gerekmektedir. İleride daha geniş türleri benimseyen ve pazarlama alanına bakış açılarını genişleten araştırmacıların ortaya çıabilmesi adına bu gibi çalışmaların ilham kaynağı olabileceği düşünülmektedir. Sonuç olarak, araştırmacıların ilerde yapacakları çalışmalarda geçerlik ve güvenirliği arttırmak için kullandıkları çeşitlendirme gibi yöntemleri arttırmaları, seçtikleri tasarım ve metodolojileri daha net bir şekilde belirtmeleri/açıklamaları ve şeffaf bir şekilde uygulamaları, ayrıca örneklem büyüklügü veya zenginliğine dikkat etmeleri beklenmektedir. Belirtilmesi gereken bir başka konu ise nicel yöntemlerden de yararlanan araştırmacılar olarak, önerilerimizin veya tartışmaların hiçbirisi pazarlama disiplini içerisindeki post pozitivist yaklaşıma sahip akademisyenleri suçlamaya yönelik değildir. Nitel yaklaşımların teşvik edilmesi ve iki paradigma arasındaki gerilimin azaltılmasıyla çok sesliliğin artacağı inancına sahibiz. Gelişmekte olan bir sosyal bilim alanı olarak pazarlama; yeni teorilere, yeni kavramlara ve yeni metotlara ihtiyaç duymaktadır. Bunu da ancak, sürekli olarak kendini gözden geçirerek ve eleştirerek gerçekleştirebilecektir (Yadav, 2010).

\section{KAYNAKÇA}

Abbott, A. (2001). Chaos of Disciplines. Chicago: University of Chicago.

Açıkalın, N., \& Kayabaşı, A. (2019). İşletmelerin Sürdürülebilir İnovasyon Faaliyetleri: Pazarlama Bakış Açısıyla Nitel Bir İnceleme. Pazarlama İçgörüsü Üzerine Çalışmalar, 5(2), 191-219.

Alam, I. (2005). Fieldwork and data collection in qualitative marketing research. Qualitative Market Research, 8(1), 97-112. https://doi.org/10.1108/13522750510575462

Alderson, W., \& Cox, R. (1948). Towards a Theory of Marketing. Journal of Marketing, 13(2), 137-152. https://doi.org/10.1177/002224294801300201

Altuntaş, C., \& Tuna, O. (2012). Endüstriyel Hizmet Satın Alma Süreci Ve Lojistik Merkezler: Bir İçerik Analizi Uygulaması. Pazarlama ve Pazarlama Araştırmaları Dergisi, (9), 21-41.

Anderson, P. F. (1986). On Method in Consumer Research: A Critical Relativist Perspective. Journal of Consumer Research, 13(2), 155. https://doi.org/10.1086/209058

Arslan, Y. (2019). Gıda Tüketim Trendlerinin Şekillenmesinde Kanaat Önderlerinin Rolü : Canan Karatay Örneği. Tüketici ve Tüketim Araştırmaları Dergisi, 11(1), 143-176.

Arslan, Z. (2019). Sürdürülebilir Kurumsal Marka Kavramı ve BİST Sürdürülebilirlik Endeksi'ndeki Firmaların Sürdürülebilir Kurumsal Marka Uygulamaları Üzerine Bir Araştırma. Pazarlama ve Pazarlama Araştırmaları Dergisi, 24, 385-415.

Atakan, S. Ş., \& Seraj, M. (2016). Evde Yemek Hazırlama Davranışının Tüketici Motivasyonu Yönünden İncelenmesi. 2Pazarlama ve Pazarlama Araştırmaları Dergisi, 18, 105-133.

Atkinson, P., Delamont, S., \& Hammersley, M. (1988). Qualitative Research Traditions: A British Response to Jacob. Review of Educational Research, 58(2), 231-250. https://doi.org/10.3102/00346543058002231

Avan, A., \& Özdemir, Ş. (2015). Zincir Otellerde Hizmet Ortamı-Kullanıcı Etkileşimi Üzerine Nitel Bir Araştırma. Tüketici ve Tüketim Araştırmaları Dergisi, 7(1), 87-131.

Baker, M. J. (1995). The Need for Theory in Marketing. In Marketing: Theory and Practice (pp. 10-22). London: Macmillan.

Bakır, N. O. (2013). Pazarlama Alanında Yapılan Doktora Tezlerinin Kategorik Olarak Değerlendirilmesi (1994 - 2012). Öneri Dergisi, 10(40), 1-13. https://doi.org/10.14783/od.v10i40.1012000344

Bansal, P., \& Corley, K. (2011). From the editors the coming of age for qualitative research: Embracing the diversity of qualitative methods. Academy of Management Journal, 54(2), 233-237. https://doi.org/10.5465/AMJ.2011.60262792

Bansal, P. T., Smith, W. K., \& Vaara, E. (2018). From the editors new ways of seeing through qualitative research. Academy of Management Journal, 61(4), 1189-1195. https://doi.org/10.5465/amj.2018.4004

Bardakcı, A., \& Akıncı, M. (2014). Türkiye'de Ürün Markalamada Yabancı Dil Kullanımı: Sebepler ve Sonuçlar. 
2Tüketici ve Tüketim Araştırmaları Dergisi, 6(1), 1-26.

Başfırıncı, Ç. (2015). Türk Atasözlerinde Alışveriş Olgusu. Tüketici ve Tüketim Araştırmaları Dergisi2, 7(2), 95116.

Başkale, H. (2016). Nitel Araştırmalarda Geçerlik, Güvenirlik ve Örneklem Büyüklüğünün Belirlenmesi. Dokuz Eylül Üniversitesi Hemşirelik Fakültesi Elektronik Dergisi, 9(1), 23-28.

Belk, R. W. (2013). Qualitative versus Quantitative Research in Marketing. Revista de Negócios, 18(1). https://doi.org/10.7867/1980-4431.2013v18n1p5-9

Belk, R. W., Sherry Jr., J. F., \& Wallendorf, M. (1988). A Naturalistic Inquiry into Buyer and Seller Behavior at a Swap Meet. Journal of Consumer Research, 14(4), 449. https://doi.org/10.1086/209128

Boddy, C. R. (2016). Sample size for qualitative research. Qualitative Market Research, 19(4), 426-432. https://doi.org/10.1108/QMR-06-2016-0053

Bozkurt, F., \& Ergen, A. (2012). Pazarlama Iletişïmïnde Yenï Bïr Mobil Pazarlama Aracı: 2 Boyutlu Barkodlar. Pazarlama ve Pazarlama Araştırmaları Dergisi, 9, 43-64.

Bulut, Z. A., Tekinbaş, F., \& Babacan, M. (2014). Okul öncesi yaş grubu çocukların pazarlama kavramları farkındalı̆̆ı. Tüketici ve Tüketim Araştırmaları Dergisi, 6(1), 27-49.

Carson, D., \& Coviello, N. (1996). Qualitative research issues at the marketing/ entrepreneurship interface. Marketing Intelligence \& Planning, 14(6), 51-58. https://doi.org/10.1108/02634509610131162

Çatı, K., \& Öcel, Y. (2018). Türkiye de Pazarlama İle İlgili Yayınlanan Makalelerin Bibliyometrik İncelenmesi. Journal of Business Research - Turk, 10(3), 508-519.

Çavuşoğlu, L., \& Atik, D. (2017). Making a Career out of Fashion Blogging. Pazarlama ve Pazarlama Araştırmaları Dergisi, 19, 33-49.

Çelebi, Ş. O., \& Bayrakdaroğlu, F. (2018). Y Kuşağı Tüketicilerinin Bilinçli Tüketim Davranışları Üzerine Bir Araştırma. Girişimcilik Inovasyon ve Pazarlama Araştırmaları Dergisi, 2(4), 111-124. https://doi.org/10.31006/gipad.415372

Çelik, Ş. S. (2019). Futbol Taraftarlığı ve Nefret Kavramlarının Marka Nefreti Kapsamında Ele Alınması: Ankaragücü Taraftarlarının Beşiktaş Nefreti. Tüketici ve Tüketim Araştırmaları Dergisi, 11(2), 321-355.

Cengiz, H., \& Başaran, S. (2016). Cep Telefonu Kullanıcılarının Tüketici Tecrübelerinin Değerlendirilmesi : Online Tüketici Yorumları Üzerine Netnografik Bir İnceleme. Tüketici ve Tüketim Araştırmaları Dergisi, $8(1), 73-92$.

Charmaz, K. (2014). Constructing grounded theory (2nd ed.). Thousand Oaks: Sage.

Colquitt, J. A., \& Zapata-Phelan, C. P. (2007). Trends in theory building and theory testing: A five-decade study of the Academy of Management Journal. Academy of Management Journal, 50(6), 1281-1303. https://doi.org/10.5465/AMJ.2007.28165855

Coşkun, A. (2018). Cebimizdeki Değerli Çöp - Cep Telefonu Atıklarında Genişletilmiş Üretici Sorumluluğu. Pazarlama İçö̈rüsü Üzerine Çalışmalar, 2(1), 35-45.

Creswell, J. W. (2007). Research Design: Qualitative, Quantitative and Mixed Method Aproaches. SAGE Publications. https://doi.org/10.4135/9781849208956

Creswell, J. W. (2013). Qualitative inquiry and research design: Choosing among five approaches (3rd ed.). Thousand Oaks: Sage.

Creswell, J. W., Hanson, W. E., Clark Plano, V. L., \& Morales, A. (2007). Qualitative Research Designs: Selection and Implementation. The Counseling Psychologist, $236-264$. https://doi.org/10.1177/0011000006287390

Crick, J. M. (2020). Qualitative research in marketing: what can academics do better? Journal of Strategic Marketing. https://doi.org/10.1080/0965254X.2020.1743738

Dalgıç, T., \& Tiltay, M. A. (2019). Marka Bağlılığına Göre Tüketici Tipolojileri: Toyota Türkiye Hayran Topluluğu Örneği. Pazarlama Teorisi ve Uygulamalan Dergisi, 5(2), 221-246.

De Kervenoael, R., Koçoğlu, İ., Uğurlu, S., \& Bozkaya, B. (2011). E-market Tedarik Zincirinde Direncin Kırılması: E-Perakende, Lojistik ve Kentsel Planlama İşbirliği. Pazarlama ve Pazarlama Araştırmaları Dergisi, 2(8), 123-136. 
M. A. Tiltay - A. Akpinar 13/1 (2021) 994-1015

Dedeoğlu, A. Ö. (2002). Tüketici Davranışları Alanında Kalitatif Araştırmaların Önemi ve Multidisipliner Yaklaşımlar. Dokuz Eylül Üniversitesi İktisadi ve İdari Bilimler Fakültesi Dergisi, 17(2), 75-92.

Dedeoğlu, A. Ö. (2004). Tüketici Davranışı Araştırmalarında Pozitivist, Yorumsamacı ve Postmodern Yaklaşımlar. Pi Dergisi, 3(10), 33-45.

Demir, Ö. (2019). Bilim Felsefesi (11. baskı). Bursa: Sentez Yayınc1lı.

Denzin, N., \& Lincoln, Y. (2005). Handbook of qualitative research (3rd ed.). SAGE.

Dixon, D. F. (1981). The Role of Marketing in Early Theories of Economic Development. Journal of Macromarketing, 1(2), 19-27. https://doi.org/10.1177/027614678100100204

Dworkin, S. L. (2012). Sample size policy for qualitative studies using in-depth interviews. Archives of Sexual Behavior, 41(6), 1319-1320. https://doi.org/10.1007/s10508-012-0016-6

Eisenhardt, K. M. (1991). Better Stories and Better Constructs: The Case for Rigor and Comparative Logic. Academy of Management Review, 16(3), 620-627. https://doi.org/10.5465/amr.1991.4279496

Eisenhardt, K. M., \& Graebner, M. E. (2007). Theory building from cases: Opportunities and challenges. Academy of Management Journal, 50(1), 25-32. https://doi.org/10.5465/AMJ.2007.24160888

Epp, A. M., \& Otnes, C. C. (2020). High-Quality Qualitative Research: Getting Into Gear. Journal of Service Research. https://doi.org/10.1177/1094670520961445

Erdoğan, B. Z. (2018). Bilim Olarak Pazarlama. Beta.

Erdoğan, B. Z., \& Doğan, V. (2012). Ekonomik İnsan'dan Sosyo-Ekonomik İnsan'a: Pazarlamanın İktisadi Temelleri ve Pazarlama İçin Bir Çıkarım. Tüketici ve Tüketim Araştırmaları Dergisi, 4(2), 11-32.

Farina, İ. A., \& Arslan, B. (2016). Managing Country Brand Image: A Content Analysis of the UK Newspapers on the Image of Turkey. Pazarlama ve Pazarlama Araştırmaları Dergisi, 17, 65-85.

Fossey, E., Harvey, C., McDermott, F., \& Davidson, L. (2002). Understanding and evaluating qualitative research. Australian and New Zealand Journal of Psychiatry, 36(6), 717-732. https://doi.org/10.1046/j.14401614.2002.01100.x

Franke, N., \& Mazanec, J. A. (2006). The six identities of marketing: A vector quantization of research approaches. European Journal of Marketing, 40(5-6), 634-661. https://doi.org/10.1108/03090560610657877

Ger, G. (2009). Tüketici Araştırmalarında Nitel Yöntemler Kullanmanın İncelikleri ve Zorlukları. Tüketici ve Tüketim Araştırmaları Dergisi, 1(1), 1-19.

Gioia, D. A., Corley, K. G., \& Hamilton, A. L. (2013). Seeking Qualitative Rigor in Inductive Research: Notes on the Gioia Methodology. Organizational Research Methods, 16(1), 15-31. https://doi.org/10.1177/1094428112452151

Giritlioğlu, İ., Tan, A., Sürme, M., \& Akmaz, A. (2019). Gaziantep'te Bulunan Yiyecek-İçecek İşletmelerinin Foursquare Yorumlarının Değerlendirilmesi. Pazarlama ve Pazarlama Araştırmaları Dergisi, 23, 81-93.

Glaser, B. G. (1965). The Constant Comparative Method of Qualitative Analysis. Social Problems, 12(4), 436445. https://doi.org/10.2307/798843

Golafshani, N. (2003). Understanding reliability and validity in qualitative research. The Qualitative Report, 8(4), 597-607. https://doi.org/10.3367/UFNr.0180.201012c.1305

Goulding, C. (1999). Consumer research, interpretive paradigms and methodological ambiguities. European Journal of Marketing, 33(9/10), 859-873. https://doi.org/10.1108/03090569910285805

Guba, E. G., \& Lincoln, Y. S. (1982). Epistemological and methodological bases of naturalistic inquiry. Educational Communication \& Technology, 30(4), 233-252. https://doi.org/10.1007/BF02765185

Guba, E. G., \& Lincoln, Y. S. (1994). Competing paradigms in qualitative research. In Handbook of qualitative research.

Guest, G., Bunce, A., \& Johnson, L. (2006). How Many Interviews Are Enough?: An Experiment with Data Saturation and Variability. Field Methods, 18(1), 59-82. https://doi.org/10.1177/1525822X05279903

Gummesson, E. (2005). Qualitative research in marketing: Road-map for a wilderness of complexityand unpredictability. European Journal of Marketing, 39(3-4 SPEC. ISS.), 309-327. https://doi.org/10.1108/03090560510581791 
M. A. Tiltay - A. Akpınar 13/1 (2021) 994-1015

Hanson, D., \& Grimmer, M. (2007). The mix of qualitative and quantitative research in major marketing journals, 1993-2002. European Journal of Marketing, 41(1-2), 58-70. https://doi.org/10.1108/03090560710718111

Healy, M., \& Perry, C. (2000). Comprehensive criteria to judge validity and reliability of qualitative research within the realism paradigm. Qualitative Market Research: An International Journal, 3(3), 118-126. https://doi.org/10.1108/13522750010333861

Holbrook, M. B., \& O'Shaughnessy, J. (1988). On the Scientific Status of Consumer Research and the Need for an Interpretive Approach to Studying Consumption Behavior. Journal of Consumer Research, 15(3), 398. https://doi.org/10.1086/209178

Hunt, S. D. (1976). The Nature and Scope of Marketing. Journal of Marketing, 40(3), 17. https://doi.org/10.2307/1249990

Hunt, S. D. (1990). Truth in Marketing Theory and Research. Journal of Marketing, 54(3), 1. https://doi.org/10.2307/1251812

Hunt, S. D. (1994). On Rethinking Marketing: Our Discipline, Our Practice, Our Methods. European Journal of Marketing, 28(3), 13-25. https://doi.org/10.1108/03090569410057263

Hunt, S. D. (2014). Understanding marketing's philosophy debates: A retrospective on seven key publication events. Journal of Historical Research in Marketing, 6(3), 351-378. https://doi.org/10.1108/JHRM-04-20130020

İşçioğlu, T. E. (2018). Sanal Market Alışverişi Niyetinin Sürekliliğini Etkileyen Unsurlar ve Bir Model Önerisi. Pazarlama ve Pazarlama Araştırmaları Dergisi, 21, 99-124.

İşçioğlu, T. E., \& Yurdakul, D. (2018). İkinci El Giyim Motivasyonları ve Sürdürülebilirlik Üzerine Keşifsel Bir Araştırma. Pazarlama Teorisi ve Uygulamaları Dergisi, 4(2), 253-280.

İşlek, M. S., \& Erdoğan, B. Z. (2019). Anadolu Yaklaşımı Mümkün mü? Türk Girişimci Biyografi ve Otobiyografileri Üzerine Bir İnceleme. Tüketim ve Tüketim Araştırmaları Dergisi, 11(2), 227-258.

Jacob, E. (1987). Qualitative Research Traditions: A Review. Review of Educational Research, 57(1), 1-50. https://doi.org/10.3102/00346543057001001

Jaskiewicz, P., Combs, J. G., \& Rau, S. B. (2015). Entrepreneurial legacy: Toward a theory of how some family firms nurture transgenerational entrepreneurship. Journal of Business Venturing, 30(1), $29-49$. https://doi.org/10.1016/j.jbusvent.2014.07.001

Jones, D. G. B., \& Monieson, D. D. (1990). Early Development of the Philosophy of Marketing Thought. Journal of Marketing, 54(1), 102. https://doi.org/10.2307/1252176

Jonsen, K., Fendt, J., \& Point, S. (2018). Convincing Qualitative Research: What Constitutes Persuasive Writing? Organizational Research Methods, 21(1), 30-67. https://doi.org/10.1177/1094428117706533

Kacar, A. İ., Kartal, B., \& Kahraman, A. (2014). Türkiye'deki Çevreci Sivil Toplum Kuruluşlarının Sosyal Pazarlama Kampanyalarının İçerik Analizi Yöntemiyle İncelenmesi. Pazarlama ve Pazarlama Araştırmaları Dergisi, 14, 47-72.

Karababa, E., \& Kjeldgaard, D. (2015). Understanding the Complexity of Value and Its Co-Constitution in a Global Network : Insights from a Global Fashion Brand Value Constitution Context. Tüketici ve Tüketim Araştırmaları Dergisi, 7(1), 1-21.

Karayün, İ., \& Uca, N. (2018). E-Lojistik Kapsamında Çevrimiçi Müşteri Portallarının Yük Operasyonlarına Etkisinin Değerlendirilmesi: Vaka Analizi. Pazarlama İçörü̈sü Üzerine Çalşmalar, 2(1), 46-56.

Kerin, R. A. (1996). In pursuit of an ideal: The editorial and literary history of the journal of marketing. Journal of Marketing, Vol. 60, pp. 1-13. https://doi.org/10.1177/002224299606000101

Kidd, S. A. (2002). The role of qualitative research in psychological journals. Psychological Methods, 7(1), 126138. https://doi.org/10.1037/1082-989X.7.1.126

Kırcova, İ., \& Köse, Ş. G. (2017). Televizyon Dizileri ve Filmlerde Ürün Yerleştirmeye Yönelik Genç Tüketicilerin Tutumlarına İlişkin Bir Nitel Araştırma. Pazarlama ve Pazarlama Araştırmaları Dergisi, 19, 51-77.

Kıymalığlu, A., \& Öztürk, B. N. (2018). “'Miraculous Formula'”: Revealing Deep-Seated Feelings of 


\section{A. Tiltay - A. Akpinar 13/1 (2021) 994-1015}

Vulnerable Consumers Raised By Infant. Tüketici ve Tüketim Araştırmaları Dergisi, 10(2), 219-264.

Koçak, A., \& Karaca, K. (2013). İşletmelerde Örgütsel Karakteristiklerin Yenilik Kapasitesi Üzerine Ortaklaşa Etkisinin Belirlenmesi. Pazarlama ve Pazarlama Araştırmalar Dergisi, 11, 21-60. Retrieved from http://www.pazarlama.org.tr/dergi/yonetim/icerik/makaleler/43-published.pdf

Korai, B., \& Souiden, N. (2019). The marketing discipline in trouble? Academic voices vying for supremacy. Management Decision, 57(9), 2555-2569. https://doi.org/10.1108/MD-02-2017-0128

Korstjens, I., \& Moser, A. (2018). Series: Practical guidance to qualitative research. Part 4: Trustworthiness and

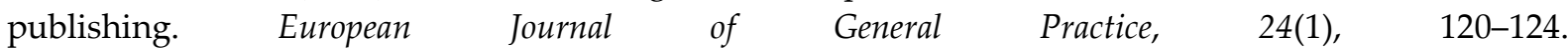
https://doi.org/10.1080/13814788.2017.1375092

Köz, Z., \& Atakan, S. Ş. (2018). Online Versus Traditional: A Comparison of Consumer Perceptions of Youtube and Tv Ads. Pazarlama ve Pazarlama Araştırmaları Dergisi, 21, 29-50.

Krefting, L. (1991). Rigor in qualitative research: the assessment of trustworthiness. The American Journal of Occupational Therapy. : Official Publication of the American Occupational Therapy Association, 45(3), 214-222. https://doi.org/10.5014/ajot.45.3.214

Kuhn, T. S., \& Hawkins, D. (1963). The Structure of Scientific Revolutions. American Journal of Physics, 31(7), 554-555. https://doi.org/10.1119/1.1969660

Kumar, V. (2015). Evolution of Marketing as a Discipline: What Has Happened and What to Look Out For. Journal of Marketing, 79(1), 1-9. https://doi.org/10.1509/jm.79.1.1

Kuzel, A. (1999). Sampling in qualitative inquiry. In Doing qualitative research (pp. 33-45).

Langley, A. (1999). Strategies for theorizing from process data. Academy of Management Review, 24(4), 691-710. https://doi.org/10.5465/AMR.1999.2553248

Lecompte, M. D., \& Goetz, J. P. (1982). Problems of Reliability and Validity in Ethnographic Research. Review of Educational Research, 52(1), 31-60. https://doi.org/10.3102/00346543052001031

Lincoln, Y. S., \& Guba, E. G. (1985). Naturalistic inquiry. In Naturalistic inquiry. Beverly Hills CA: Sage.

Lincoln, Y. S., \& Guba, E. G. (2000). Paradigmatic controversies, contradictions and emerging confluences. In Handbook of Qualitative Research, 2nd ed.

MacInnis, D. J. (2005). Them versus us: woes on the bifurcation of academic marketing discipline. Journal of Marketing, 69(4), 25-29.

Marshall, B., Cardon, P., Poddar, A., \& Fontenot, R. (2013). Does sample size matter in qualitative research?: A review of qualitative interviews in is research. Journal of Computer Information Systems, 54(1), 11-22. https://doi.org/10.1080/08874417.2013.11645667

Marshall, C., \& Rossman, G. B. (2016). Designing Qualitative Research (Sixth edit). Thousand Oaks: Sage.

Mays, N., \& Pope, C. (1995). Rigour and qualitative research. British Medical Journal, 311(6997), 109-112. https://doi.org/10.1136/bmj.311.6997.109

Miles, M.B \& Huberman, A. . (1994). An expanded sourcebook: Qualitative data analysis (2nd Edition). In Sage Publications.

Morrow, S. L. (2005). Quality and trustworthiness in qualitative research in counseling psychology. Journal of Counseling Psychology, 52(2), 250-260. https://doi.org/10.1037/0022-0167.52.2.250

Özbakır, M., \& Velioğlu, N. M. (2010). Pazarlamaya Sürdürülebilirlik Çerçevesinden Bakış ve Bir Örnek Olay Analizi. Tüketici ve Tüketim Araştırmaları Dergisi, 2(2), 71-98.

Özdemir, Ö. G., \& Özer, D. (2016). Siyasal Pazarlamada Bütünleşik Pazarlama İletişimi ve Siyasi Partilerce Algılanan Toplum: Göstergebilimsel Bir Analiz. Pazarlama ve Pazarlama Araştırmaları Dergisi, 18, 31-66.

Patton, M. Q. (2002). Qualitative research and evaluation methods (3rd ed.). Thousand Oaks: Sage.

Peter, J. P., \& Olson, J. C. (1983). Is Science Marketing? Journal of Marketing, 47(4), 111. https://doi.org/10.2307/1251404

Pratt, M. G. (2009). From the editors: For the lack of a boilerplate: Tips on writing up (and reviewing) qualitative research. Academy of Management Journal, 52(5), 856-862. https://doi.org/10.5465/AMJ.2009.44632557 
Pratt, M. G. (2008). Fitting oval pegs into round holes: Tensions in evaluating and publishing qualitative research in top-tier North American journals. Organizational Research Methods, 11(3), 481-509. https://doi.org/10.1177/1094428107303349

Pratt, M. G., Kaplan, S., \& Whittington, R. (2020). Editorial Essay: The Tumult over Transparency: Decoupling Transparency from Replication in Establishing Trustworthy Qualitative Research*. Administrative Science Quarterly, 65(1), 1-19. https://doi.org/10.1177/0001839219887663

Reibstein, D. J., Day, G., \& Wind, J. (2009). Guest Editorial: Is Marketing Academia Losing Its Way? Journal of Marketing, 73(4), 1-3. https://doi.org/10.1509/jmkg.73.4.001

Sabah, Ş. (2017). Ben, Kendim ve Avatarım: Sanallık ve Gerçeklik Arasında Tüketim, Sahip Olunanlar ve Kişisel Benlik. Tüketici ve Tüketim Araştırmaları Dergisi, 9(1), 117-154.

Sağlam Arı, G., Armutlu, C., Güneri Tosunoğlu, N., \& Yücel Toy, B. (2009). Pozitivist ve Postpozitivist Paradigmalar Çerçevesinde Metodoloji Tartışmalarının Yönetim ve Pazarlama Alanlarına Yansımaları. Hacettepe Üniversitesi İ̈BF Dergisi, 27(1), 113-141.

Schatzki, T. R. (2012). A Primer on Practices: Theory and Research. In Practice-Based education: Perspectives and Strategies (pp. 25-26). Rotterdam: Sense Publishers.

Schwandt, T. A. (1994). Constructivist, interpretivist approaches to human inquiry. Handbook of Qualitative Research.

Sinkovics, R. R., \& Alfoldi, E. A. (2012). Progressive Focusing and Trustworthiness in Qualitative Research: The Enabling Role of Computer-Assisted Qualitative Data Analysis Software (CAQDAS). Management International Review, 52(6), 817-845. https://doi.org/10.1007/s11575-012-0140-5

Starr, M. A. (2014). Qualitative and mixed-methods research in economics: Surprising growth, promising future. Journal of Economic Surveys, 28(2), 238-264. https://doi.org/10.1111/joes.12004

Svensson, G. (2006). The paradoxnoia of top journal(s) in marketing. European Journal of Marketing, 40(11-12), 1153-1168. https://doi.org/10.1108/03090560610702740

Tesch, R. (1990). Qualitative research: Analysis types and software tools. New York: Falmer.

Tosey, P., Lawley, J., \& Meese, R. (2014). Eliciting Metaphor through Clean Language: An Innovation in Qualitative Research. British Journal of Management, 25(3), 629-646. https://doi.org/10.1111/14678551.12042

Tracy, S. J. (2010). Qualitative quality: Eight a"big-tent" criteria for excellent qualitative research. Qualitative Inquiry, 16(10), 837-851. https://doi.org/10.1177/1077800410383121

Tucker, M. L., Powell, K. S., \& Dale Meyer, G. (1995). Qualitative Research in Business Communication: A Review and Analysis. Journal of Business Communication, 32(4), 383-399. https://doi.org/10.1177/002194369503200405

Tufan, F., \& Özdil, A. F. S. (2012). Pazarlama İletişiminde Yeni Bir Mecra: Mağaza Radyoculuğu (In Store Radio). Pazarlama ve Pazarlama Araştırmaları Dergisi, 9, 103-116.

Tufford, L., \& Newman, P. (2012). Bracketing in qualitative research. Qualitative Social Work, 11(1), 80-96. https://doi.org/10.1177/1473325010368316

Webster, F. E., \& Lusch, R. F. (2013). Elevating marketing: Marketing is dead! Long live marketing! Journal of the Academy of Marketing Science, 41(4), 389-399. https://doi.org/10.1007/s11747-013-0331-z

Welch, C., Piekkari, R., Plakoyiannaki, E., \& Paavilainen-Mäntymäki, E. (2011). Theorising from case studies: Towards a pluralist future for international business research. Journal of International Business Studies, 42(5), 740-762. https://doi.org/10.1057/jibs.2010.55

Whittemore, R., Chase, S. K., \& Mandle, C. L. (2001). Validity in qualitative research. Qualitative Health Research, 11(4), 522-537. https://doi.org/10.1177/104973201129119299

Wolcott, H. T. (2009). Writing up qualitative research (3rd ed.). Thousand Oaks: Sage.

Yadav, M. S. (2010). The decline of conceptual articles and implications for knowledge development. Journal of Marketing, 74(1), 1-19. https://doi.org/10.1509/jmkg.74.1.1

Yıldırım, E. (2002). ' “Cogito ergo sum"'dan' “vivo ergo sum”'’a örgütsel analiz. Yönetim Araştırmaları Dergisi, 2(2), 155-185. 
M. A. Tiltay - A. Akpınar 13/1 (2021) 994-1015 